Winter 2019

\title{
Quantifying the magnitude and spatial variability of bedrock erosion beneath the Sisters Glacier, Washington, using cosmogenic $3 \mathrm{He}$ concentrations
}

Sarah W. Francis

Western Washington University, francis3@wwu.edu

Follow this and additional works at: https:// cedar.wwu.edu/wwuet

Part of the Geology Commons

\section{Recommended Citation}

Francis, Sarah W., "Quantifying the magnitude and spatial variability of bedrock erosion beneath the Sisters Glacier, Washington, using cosmogenic 3He concentrations" (2019). WWU Graduate School Collection. 857.

https://cedar.wwu.edu/wwuet/857 
Quantifying the magnitude and spatial variability of bedrock erosion beneath the Sisters Glacier, Washington, using cosmogenic ${ }^{3} \mathrm{He}$ concentrations

By

Sarah Francis

Accepted in Partial Completion

of the Requirements for the Degree

Master of Science

\section{ADVISORY COMMITTEE}

Dr. Doug H. Clark, Chair

Dr. Colin Amos

Dr. Ken Farley

Dr. Paul Bierman

GRADUATE SCHOOL

Dr. Gautam Pillay, Dean 


\section{Master's Thesis}

In presenting this thesis in partial fulfillment of the requirements for a master's degree at Western Washington University, I grant to Western Washington University the non-exclusive royalty-free right to archive, reproduce, distribute, and display the thesis in any and all forms, including electronic format, via any digital library mechanisms maintained by WWU.

I represent and warrant this is my original work, and does not infringe or violate any rights of others. I warrant that I have obtained written permissions from the owner of any third party copyrighted material included in these files.

I acknowledge that I retain ownership rights to the copyright of this work, including but not limited to the right to use all or part of this work in future works, such as articles or books.

Library users are granted permission for individual, research and non-commercial reproduction of this work for educational purposes only. Any further digital posting of this document requires specific permission from the author.

Any copying or publication of this thesis for commercial purposes, or for financial gain, is not allowed without my written permission.

Sarah Francis

February 2019 
Quantifying the magnitude and spatial variability of bedrock erosion beneath the Sisters Glacier, Washington, using cosmogenic ${ }^{3} \mathrm{He}$ concentrations

\author{
A Thesis \\ Presented to \\ The Faculty of \\ Western Washington University
}

In Partial Fulfillment

Of the Requirements for the Degree

Master of Science

by

Sarah Francis

February 2019 


\begin{abstract}
Cosmogenic ${ }^{3} \mathrm{He}$ analyses provide a tool to infer spatial variation of cirque-glacial bedrock erosion. ${ }^{3} \mathrm{He}$ accumulates in bedrock exposed at the surface as a result of cosmic ray bombardment; the concentration of cosmogenic ${ }^{3} \mathrm{He}$ increases with exposure time as well as proximity to the surface. The Twin Sisters range, North Cascades, WA is an ideal location to use cosmogenic ${ }^{3} \mathrm{He}$ to infer cirque-glacial erosion depths and rates, due to the dunite bedrock and the detailed record of Holocene glaciation from the nearby Mount Baker. We used field mapping, lidar data and aerial imagery to identify bedrock fractures, glacial fluting, and terminal moraines to establish the maximum Holocene extent of the Sisters Glacier. We collected bedrock samples along glacial flow-line transects in the forefield of the Sisters Glacier, as well as several samples outside the limit of Holocene glaciation. Concentrations of cosmogenic ${ }^{3} \mathrm{He}$ in all samples were calculated based on ${ }^{3} \mathrm{He} /{ }^{4} \mathrm{He}$ ratios found in shielded samples from a nearby quarry because standard crushing techniques did not remove mantle-sourced ${ }^{3} \mathrm{He}$ from the samples, introducing a significant amount of uncertainty. Our analyses of forefield samples show decreasing exposure ages (10,500-0 yrs) and increasing depths of erosion $(0.15-146 \mathrm{~cm})$ with proximity to the modern glacier. The patterns in erosion rates are more difficult to discern due to larger uncertainties, but potentially show increasing rates of subglacial erosion (0.001-0.7 $\mathrm{mm} / \mathrm{yr}$ ) with proximity to the modern glacier. These rates are consistent with those proposed by previous studies; however, the relatively low and consistent erosion rates suggest that abrasion and/or small quarrying events (centimeters to decimeters) are the dominant mechanisms of erosion underneath the Sisters Glacier. This study helps to better understand how cirque glaciers shape mountain topography.
\end{abstract}




\section{Acknowledgements}

This research would not have been possible without the support and commitment of many, many people. A very special thank you to my field assistant team, who donated their time and energy to helping me complete my field work: bushwhacking through steep, rugged terrain, leading our search for a safe route up a cliff, spending many nights in the alpine wilderness, stuffing our backpacks full of rocks, sharing backpacking recipes, and remaining optimistic through it all. Annalise Rubida, Anthony Semeraro, Ben Kalapus, Maggie Neer, Venice Wong: thank you all so much. Thank you also to Weyerhaeuser for providing a gate key free of charge, slicing off four miles from our trek to the field area.

Thank you to Dr. Bob Mitchell for doing a DHSVM model run for my field area, greatly improving my snow shielding calculations. Thank you to Dr. Sean Mulcahy for helping with thin section mineral identification, and to Dr. Mike Kraft for helping run rock thin sections through the SEM. And thank you to Ben Paulson for support with WWU lab equipment, including the rock saw, rock crushers, and thin section equipment. Thank you to the Caltech Noble Gas Lab for welcoming me into their lab space twice during this project, and thank you to Jonathan Treffkorn for patiently guiding me through running samples through the mass spectrometer. A final thank you to all faculty at WWU for supporting and guiding me through my education.

Thank you to my research committee, who graciously guided me through the growth and development of this project: Dr. Doug Clark, Dr. Colin Amos, Dr. Ken Farley, and Dr. Paul Bierman.

Thank you to my funding sources: California Institute of Technology, WWU Department of Geology, WWU Graduate School, and the Northwest Scientific Association.

Finally, this research would not have been possible without the support of my loving family and friends. A special thank you to Kristiana Lapo, for continued intellectual and emotional support, and for accompanying me to Caltech to run our separate rock samples together. Thank you to Ticika Dominick for being the best roommate and friend I could ever ask for, and for believing in me throughout my entire education at WWU. A final thank you to my loving parents and grandparents, who have always supported me from afar. 


\section{Table of Contents}

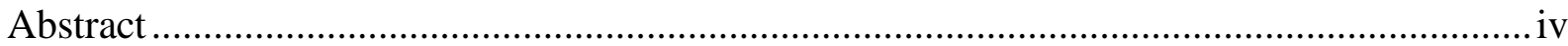

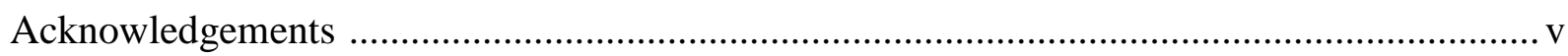

List of Tables and Figures........................................................................................ vii

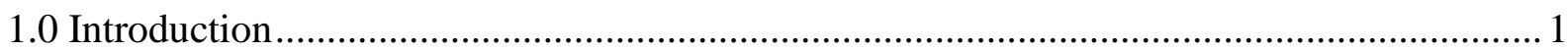

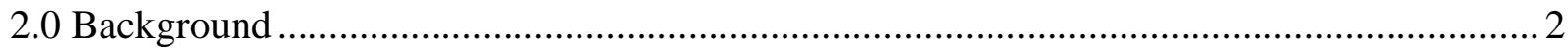

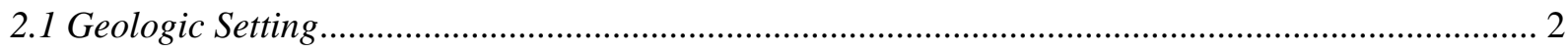

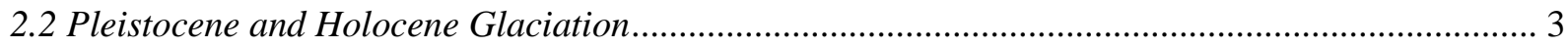

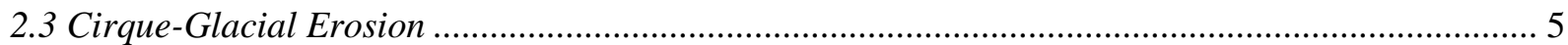

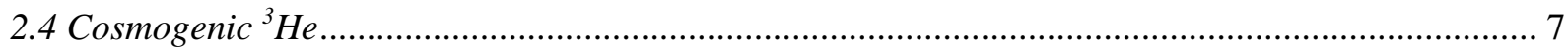

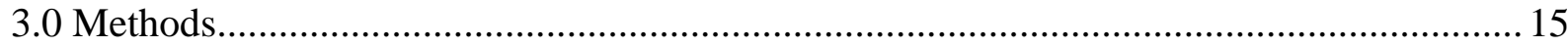

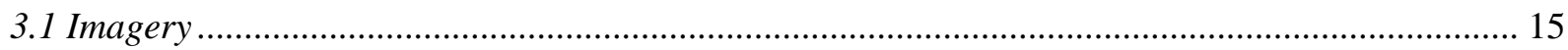

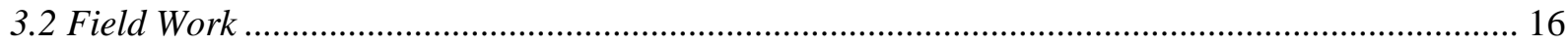

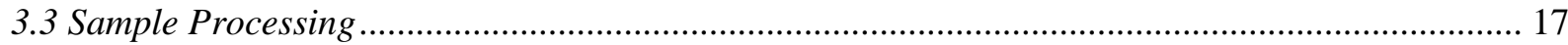

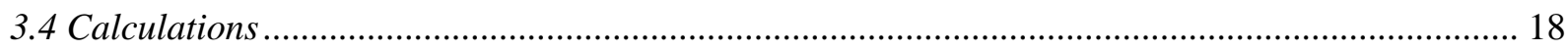

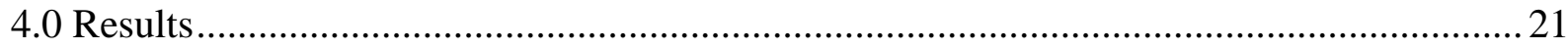

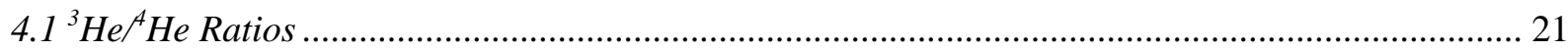

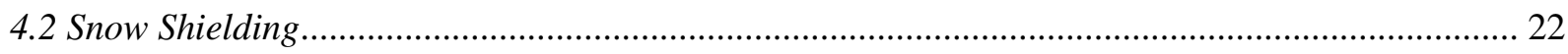

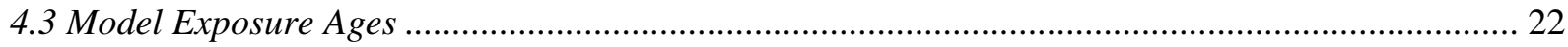

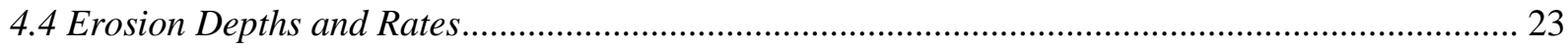

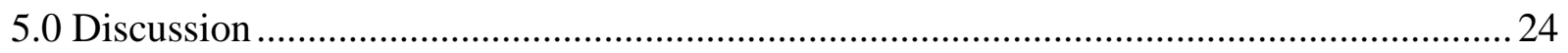

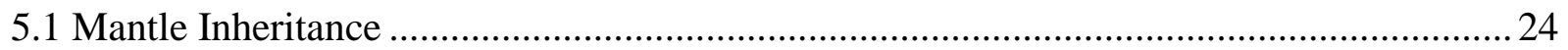

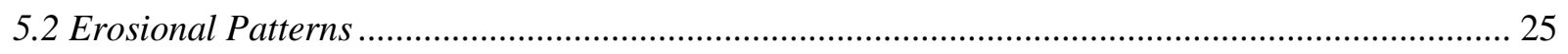

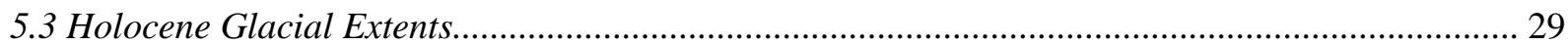

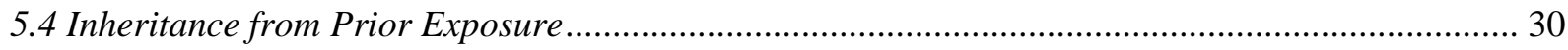

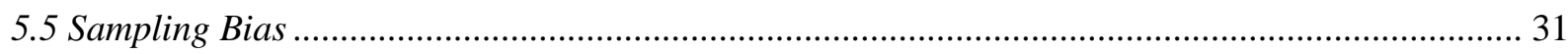

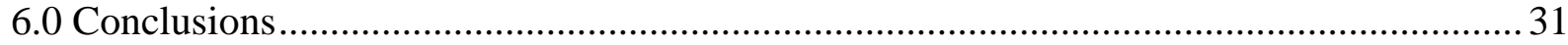

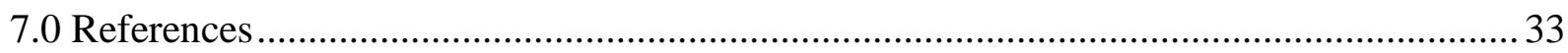

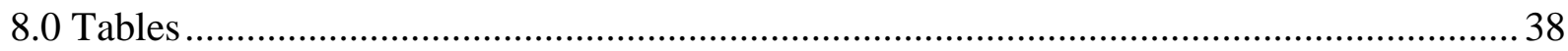

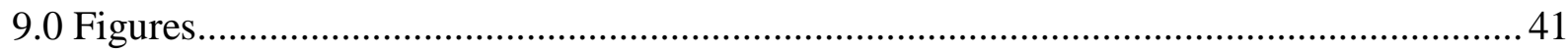




\section{List of Tables}

Table 1: Measured ${ }^{3} \mathrm{He}$ and ${ }^{4} \mathrm{He}$ concentrations in all samples ........................................... 38

Table 2: Snow shielding correction estimates from DHSVM and SNOTEL sites ..................39

Table 3: Sample locations, observations, model exposure ages, and erosion depths and rates 40

\section{List of Figures}

Figure 1: Simplified geologic map of the Twin Sisters Range ........................................ 41

Figure 2: SNOTEL site locations used for snow shielding calculations ............................. 42

Figure 3: Cartoon schematic showing subglacial erosion of accumulated ${ }^{3} \mathrm{He}$...................... 43

Figure 4: Lidar hillshade showing prominent geomorphological features .......................... 43

Figure 5: Lidar hillshade and Google Earth images indicating Neoglacial ice limit.............. 44

Figure 6: Historical extents of the Sisters Glacier ......................................................... 45

Figure 7: Location of Sven Larsen quarry and DHSVM sites ........................................ 46

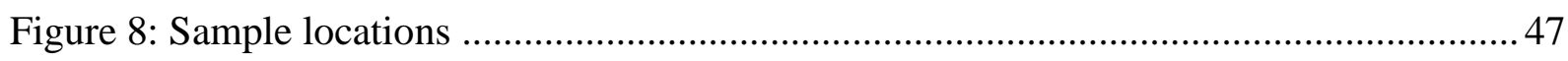

Figure 9: Estimated locations of Neoglacial termini and sample locations .......................... 48

Figure 10: ${ }^{3} \mathrm{He} /{ }^{4} \mathrm{He}$ plot of exposed samples at multiple grain size fractions ........................ 49

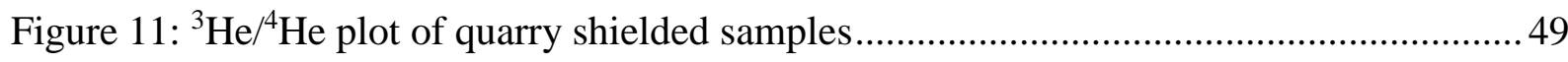

Figure 12: Lowland sample sites and model exposure ages ............................................50

Figure 13: Forefield sample sites, model exposure ages, and distance from modern glacier... 51

Figure 14: Forefield sample sites, model erosion depths, and distance from modern glacier.. 52

Figure 15: Forefield sample sites, model erosion rates, and distance from modern glacier.....53 


\subsection{Introduction}

Cirque glaciers are common in temperate mountains around the world, and thereby are a dominant agent of erosion in these high mountain settings (e.g., Anderson, 1978; Larsen and Mangerud, 1981; National Snow and Ice Data Center, 2017). The processes and rates of this erosion, however, are not well-understood (Koppes et al., 2015). The Twin Sisters Mountains, in western Washington State, are an excellent location to study cirque-glacial erosion because of their unusual dunite lithology, which permits use of an easily measured cosmogenic isotope erosion proxy. These mountains are the western-most glacier-bearing mountains in the North Cascades, located just southwest of Mount Baker in Washington State (Figure 1). In this study, we measured cosmogenic ${ }^{3} \mathrm{He}$ in bedrock samples to quantify the magnitude and spatial variability of bedrock erosion beneath the Twin Sisters Glacier in order to better understand how cirque glaciers shape mountain topography.

Current understanding of cirque sub-glacial erosional rates and mechanisms is limited. Published values for cirque-glacial erosion rates are rare and highly variable $(0.008-10 \mathrm{~mm} / \mathrm{yr})$, and mostly rely on indirect estimates from sediment volumes (e.g., Sanders et al., 2013; Herman et al., 2015) or theoretical models (Iverson, 2012; Anderson, 2014). Sediment volume methods are imprecise, and theoretical models of cirque-glacial erosion have poorly constrained parameters, reflecting our limited understanding of glacial bedrock erosional processes (Herman et al., 2015). Published studies on cirque glacial erosion rates produce variable results without spatial resolution, underpinning the need for more direct measurements of erosion rates in order to advance our understanding of processes and rates of cirque-glacial erosion (Delmas et al., 2009). 
Terrestrial cosmogenic nuclide (TCN) analysis provides a tool to infer bedrock erosion beneath glaciers at distinct locations (Briner and Swanson, 1998; Fabel et al., 2004; Crest et al., 2017). This technique relies on TCNs that are produced dominantly within the uppermost few meters of rock by cosmic ray bombardment at Earth's surface. Abundance of TCNs in bedrock depends on surface exposure time as well as post-exposure depth of erosion; abundance increases with surface exposure time, but decreases as surface erosion removes accumulated TCNs (Gosse and Phillips, 2001). The dunite bedrock in the Twin Sisters Range, which is greater than 90 percent olivine (Christensen, 1971), presents an opportunity to employ ${ }^{3} \mathrm{He} \mathrm{TCN}$ analysis to test rates and mechanisms of Holocene cirque glacial erosion. Olivine is one of the few minerals that retains cosmogenic ${ }^{3} \mathrm{He}$, as a result of its dense crystal structure (Kurz and Brook, 1994). This study is the first to use cosmogenic ${ }^{3} \mathrm{He}$ to examine cirque-glacial erosion rates.

By analyzing the abundance of cosmogenic ${ }^{3} \mathrm{He}$ in recently deglaciated bedrock, this study provides direct estimates of the magnitude and spatial variability of erosion underneath a cirque glacier. Because cirque glaciers are globally abundant and are dominant agents of erosion in mountain environments (Koppes et al., 2015), this knowledge is fundamental to improving model constraints of landscape evolution in glaciated alpine settings.

\subsection{Background}

\subsection{Geologic Setting}

The Twin Sisters Range is located in Washington State, approximately six kilometers southwest of Mount Baker and thirty kilometers east of Bellingham (Figure 1). The range is part of the North Cascades, which extend from central Washington State to southwestern British Columbia. The Twin Sisters rise to approximately 2,100 meters above sea level, and the small glaciers that persist on the northeastern slopes drain into the Middle Fork Nooksack River 
watershed. The Twin Sisters Range is unusual in that it is composed nearly entirely of dunite bedrock (Figure 1); Twin Sisters dunite is approximately 93 percent olivine, five percent enstatite, and two percent chromite (Christensen, 1971). Locally, the bedrock is overlain by Quaternary alluvium, glacial till, and mass-wasting deposits (Tabor et al., 2003). Although its origin is not well understood, Ragan (1963) concluded that the dunite body was uplifted from the mantle along a steeply-inclined thrust fault after Cretaceous orogenic contraction. The main dunite block is elliptical, approximately 16 kilometers long, 5-6 kilometers wide, and 2 kilometers deep (Tikoff et al., 2010), making it not only the largest contiguous block of dunite in the world, but also the only one that has been heavily glaciated. This unusual geologic setting makes the Twin Sisters Range a unique location to use ${ }^{3} \mathrm{He}$ TCN measurements to study glacial erosion.

\subsection{Pleistocene and Holocene Glaciation}

The North Cascades were sculpted by repeated periods of glaciation throughout the Quaternary (Easterbrook, 1969; Porter, 1976; Porter and Swanson, 1998; Kovanen and Easterbrook, 2001; Riedel et al., 2010), and the Twin Sisters Range was continuously glaciated from approximately 25,000 to 11,000 years ago (Armstrong et al., 1965; Porter, 1976; Thorson, 1980; Osborn et al., 2012). Beginning early in marine oxygen isotope stage 2 (MIS 2), glaciers covered much of the North Cascades and advanced into the lowlands during what is termed the Evans Creek stade ( 30,000-19,500 cal yr B.P.) (Armstrong et al., 1965; Riedel et al., 2010); directly following this event, a major advance of the Cordilleran Ice Sheet during the Vashon stade buried the Puget lowlands and the northern North Cascades, including most of the Twin Sisters Range, under even thicker ice, with only the highest peaks of Mt. Baker, Mt. Shuksan, and the Twin Sisters remaining above the ice as isolated nunataks (e.g., Booth et al., 2003). 
Following its maximum extent, the Cordilleran Ice Sheet rapidly decayed, retreating north of the International Boundary by 14,000 cal ka BP (Clague et al., 1997; Clark and Steig, 2008); however, large alpine glaciers likely persisted in many areas, including in the Twin Sisters region until 11,000 cal yr BP, the end of the Sumas Stade of the Cordilleran Ice Sheet (Clague et al., 1997; Kovanen and Easterbrook, 2001; Menounos et al., 2009).

There are well-documented records of Holocene glaciation from several glaciers (Coleman, Easton, Deming) on the adjoining slopes of Mount Baker (Harper, 1993; Osborn et al., 2012). Because of the close proximity of these glaciers to the Twin Sisters Range (directly across the Middle Fork Nooksack River) and their nearly identical climatic conditions, it is reasonable to use the Mount Baker glacial record as a proxy for Holocene glaciation in the Twin Sisters relative to modern extents (Osborn et al., 2012). The Cordilleran Ice sheet receded $\sim 11,000$ cal yr B.P., but glaciers on Mt. Baker persisted at reduced extents relative to modern conditions through the early and mid-Holocene (Kovanen and Easterbrook, 2001; Riedel, 2007; Menounos et al., 2009; Riedel et al., 2010; Osborn et al., 2012). Neoglaciation began around 2,300 cal. yr BP (Osborn et al., 2012; Wershow, 2016). Although Mount Baker glaciers may have had one or two minor advances before this time, only advances younger than 2,300 years ago are sustained and well-documented in multiple locations. Based on the Baker record, starting $\sim 2,300$ cal. yr BP, glaciers in the area began a series of advances and retreats with successively larger extents, before reaching their Holocene maxima during the Little Ice Age (last 800 years) (Osborn et al., 2012). Most of the cirques on the east side of the Twin Sisters were occupied by small glaciers at the peak of the Little Ice Age ( 1850 CE). (Osborn et al., 2012). Between the late 1800's to early 1900's CE, glaciers disappeared from all but two of the cirques in the Twin Sisters. The remaining Twin Sisters glaciers likely continued to retreat until about 1950, when 
they experienced a period of stability and minor growth until the 1990s. Since the 1990s, the glaciers in the Mt. Baker area have been retreating steadily (Harper, 1993; Dick, 2013). This detailed proxy record of Holocene glacier extents for the Sisters Glacier provides a crucial constraint on timing of Holocene glaciation necessary to estimate rates of erosion beneath the glacier.

\subsection{Cirque-Glacial Erosion}

Current estimates and models of glacial erosion rates, although becoming progressively more sophisticated, have not resulted in a comprehensive understanding of the controls on glacial erosion rates and processes (Herman et al., 2015). Furthermore, proposed theories of glacial erosion often do not match well with observations (e.g., Bennett et al., 1999; Riihimaki, 2005). Despite this limited understanding, several factors likely control rates and mechanisms of glacial erosion. First principles relating subglacial erosion to ice flow velocity suggest that fasterflowing ice will result in more rapid erosion (Hallet, 1996; Iverson, 2012). Flow velocities are dominantly a function of slope and ice thickness; thick glaciers on steep slopes will flow more quickly than thin glaciers on gentle slopes (Herman et al., 2015). Other research, however, has shown that glacial erosion rates may be more strongly controlled by subglacial meltwater and thermal regime than sliding velocity (Koppes et al., 2015). Several studies have shown that as a general trend, glacial erosion rates decrease with increasing latitude. Cold-based ice in polar regions is frozen to the bedrock, and prevents sliding, abrasion, and quarrying (Anderson, 1978; Larsen and Mangerud, 1981; Koppes et al., 2015). The highest erosion rates occur in temperate regions with warm-based ice, where abundant subglacial meltwater promotes basal sliding (Delmas et al., 2009; Koppes et al., 2015). Although many researchers have successfully measured basin-wide rates of glacial erosion, determining the mechanisms of this erosion is 
difficult because of site access and problems measuring erosion directly (Herman et al., 2015; Crest et al., 2017). Glacial ice erodes bedrock primarily by abrasion, in which the ice scrapes away at the bedrock like sandpaper, and quarrying, where the ice plucks large blocks of bedrock (Barr and Spagnolo, 2015). In general, quarrying has been shown to result in higher bedrock erosion rates than abrasion (Briner and Swanson, 1998; Belknap, 2009; Duhnforth et al., 2010). Some research suggests that the thermal regime and the amount of subglacial meltwater, as well as ice surface slope and ice thickness, control the relative strengths of these two processes on any particular glacier (Herman et al., 2015; Koppes et al., 2015). Subglacial meltwater in warmbased glaciers may enhance abrasion, but it also may promote quarrying, due to daily temperature and pressure cycles that break away large blocks of bedrock beneath the ice (Barr and Spagnolo, 2015). Rock type may also influence the mechanisms of glacial erosion, but this control is poorly-understood (Duhnforth et al., 2010). The abundance, orientation, and spacing of bedrock fractures has been shown to influence the dominance of quarrying as an erosional mechanism, with more heavily fractured bedrocks being more susceptible to quarrying, and thus more rapid erosion (Duhnforth et al., 2010; Anderson, 2014; Becker et al., 2014). More research is needed in order to understand more fully the controls and relative effectiveness of these processes.

Published values for cirque-glacier erosion rates are rare and highly variable (0.008-10 $\mathrm{mm} / \mathrm{yr}$ ) (Sanders et al., 2013). Indirect estimates from down-valley sediment volumes do not differentiate among sediments that were abraded, quarried, or supplied supraglacially (Delmas et al., 2009). Furthermore, many cirque-glaciers do not have down-valley sediment traps, or preserve moraines, making it difficult to measure sediment volumes (Riihimaki, 2005). Theoretical models of cirque-glacial erosion are sophisticated, but have poorly-constrained 
parameters, due to our limited understanding of physical erosional processes (Herman et al., 2015). A method to accurately measure spatial variability in bedrock erosion depth is needed in order to better understand how cirque glaciers shape mountain topography.

\subsection{Cosmogenic ${ }^{3} \mathrm{He}$}

Measurements of terrestrial cosmogenic nuclide $(\mathrm{TCN})$ concentrations provide a tool to directly infer depths and thus rates of bedrock erosion beneath glaciers. This method relies on measurements of cosmogenic isotopes that are produced dominantly in the upper few meters of rocks and sediments by cosmic ray bombardment at the surface. Cosmic rays are high-energy particles that strike the Earth's surface from all directions (Gosse and Phillips, 2001; Dunai, 2010). The dominant mechanism of TCN production in bedrock is spallation, which occurs when a highly energetic cosmic-ray induced neutron collides with a target nucleus, breaking it into smaller, lighter atomic pieces (Kurz and Brook, 1994). Incidence of spallation reactions decreases exponentially with depth, and is primarily a factor in the top few meters of rock (Dunai, 2010). TCN production via muons, however, may continue to much greater depths below the surface (Heisinger et al., 2002).

Of the several TCNs that are commonly used for surface exposure dating, cosmogenic ${ }^{3} \mathrm{He}$ is particularly well-suited for studying glacial erosion in the Twin Sisters Range because of the olivine-rich bedrock. ${ }^{3} \mathrm{He}$ analysis can be done with conventional noble gas mass spectrometers, which are less expensive to operate than the accelerator mass spectrometers that are required for most other TCN isotopes (Kurz and Brook, 1994; Amidon and Farley, 2011). Furthermore, cosmogenic ${ }^{3} \mathrm{He}$ can be detected at very low concentrations (only 5,000-10,000 atoms total are needed), and has a relatively rapid production rate of approximately 115-130 atoms $\mathrm{g}^{-1} \mathrm{yr}^{-1}$ at sea level and high latitude. (Kurz and Brook, 1994; Licciardi et al., 1999; Dunai 
and Wijbrans, 2000; Stone, 2000; Goehring et al., 2010). Because of these characteristics, only small rock samples are needed, this technique can be applied to very young surfaces $(<1,000$ years old), and returns useful results at timescales within the Holocene (Kurz and Brook, 1994; Heineke et al., 2016). Because it is a noble gas, over time, some cosmogenic ${ }^{3} \mathrm{He}$ can be lost from mineral grains through diffusion, but this loss is very slow in olivine and clinopyroxene, and is negligible on timescales less than 10 million years (Kurz and Brook, 1994). Other minerals, such as quartz and feldspar, do not retain helium well (Kurz and Brook, 1994; Dunai, 2010). Additionally, production rates of cosmogenic ${ }^{3} \mathrm{He}$ in olivine have been determined empirically in many studies (Cerling and Craig, 1994; Licciardi et al., 1999; Dunai and Wijbrans, 2000; Balco et al., 2008; Goehring et al., 2010).

The rate of TCN production for any given isotope varies depending on altitude, latitude, depth below the surface, and variations in strength of the magnetic field through time (Lal, 1998). Constraining these parameters is relatively straightforward in most settings. In addition, though, because TCN concentrations rely on exposure at the surface, anything that can absorb cosmic rays (e.g., snow and surrounding topography) may shield the bedrock surface from full doses of cosmic rays. It is necessary to correct for these effects in order to obtain an accurate local production rate (Gosse and Phillips, 2001; Schildgen et al., 2005; Balco, 2006). Topographic shielding corrections can be calculated using horizon angle measurements in the field or with digital elevation models. Shielding effects from snowpack are ordinarily not very significant due to the low density of snow and prominence of sample locations. However, in alpine environments where snow accumulation is high and persistent for many months, this shielding effect can be quite significant (Schildgen et al., 2005). The field site in this study is at a relatively high elevation ( 1,200-1,700 meters above sea level) on a north-facing slope, and 
normally retains snowpack from late October through June or early July. As such, is important to consider degree of shielding from snowpack during the Holocene in order to generate ${ }^{3} \mathrm{He}$ production rates.

The most common method for accounting for snow shielding in TCN studies involves using modern measurements of snowpack, which is then assumed to represent snowpack throughout the period of exposure (e.g., Tschudi et al., 2000). Other studies simply make no snow shielding correction, with the assumption that most TCN samples are taken from atop large boulders or outcrops where snowpack is presumed to have been kept to a minimum by windscour and to melt relatively early in the ablation season (e.g., Ivy-Ochs et al., 1999). In the Twin Sisters, established records of Holocene glaciation and climate indicate that it is unlikely that modern snowpack is representative of snowpack during the period of exposure (Heusser et al., 1985; Pellatt et al., 2000; Osborn et al., 2012). Additionally, samples in this study were collected from bedrock surfaces, which are not prominent enough to follow the assumptions of negligible snow-shielding. The most practical method for calculating snow shielding effects in this study uses a combination of modern snowpack data and paleoclimate proxies to estimate snow cover during the period of exposure (Schildgen et al., 2005). Modern snowpack data can be retrieved from nearby SNOTEL stations, and can be used in combination with the Distributed Hydrology Soil Vegetation Model (DHSVM) to account for local variability of snowpack due to slope aspect and elevation. The model performs an energy and water balance on a gridded digital elevation model and uses meteorological inputs to simulate hydrology outputs, including snowpack (Wigmosta et al., 2002). Because this model accounts for local variability in topography, land cover, and soil type, it can provide more accurate modern snowpack measurements than simple lapse rates in the Twin Sisters study area. 
Several paleoclimate proxies indicate how glaciation and snowpack may have fluctuated in the study area throughout the Holocene. Records of glaciation show that this area was fully glaciated by the Cordilleran Ice Sheet until $\sim 11,000$ years ago, when the Cordilleran ice sheet retreated rapidly (Booth et al., 2003, Clark and Clague, 2018 (in review)). "Neoglaciation" resulted in re-advance of glaciers beginning 2,300 years BP, and ending about 150 years ago, at the end of the Little Ice Age, when glaciers began to retreat to their current extents (Osborn et al., 2012). Whenever overridden by the Sisters Glacier during Neoglaciation, bedrock in the study area would have been completely shielded from cosmic rays, due to the absence of muonic ${ }^{3}$ He production (Dunai, 2010; Amidon and Farley, 2011). During all other times, snowpack likely caused some degree of shielding from cosmic rays. Evidence from paleoclimate proxies provides insight into how this snowpack may have fluctuated. Theoretical evidence from variation in the Earth's orbit (Milankovitch Cycles) suggests that the early Holocene was warmer than today (Clague and Mathewes, 1989; Whitlock, 1992). This inference is supported by nearby paleoecological investigations of pollen species, plant macrofossils, and chironomids, that show a warm and dry period from 11,000 years BP to 7,000 years BP (Mathewes and Heusser, 1981; Whitlock, 1992; Pellatt et al., 2000; Palmer et al., 2002; Walker and Pellatt, 2003).

Reconstructions based on pollen records estimate average annual precipitation to be $40-50 \%$ less and temperatures 1-3 degrees higher than today (Whitlock, 1992). Paleoclimate proxy records show the beginning of cooler and wetter conditions beginning around 7,000 to 6,000 years BP (Mathewes and Heusser, 1981; Whitlock, 1992; Pellatt et al., 2000; Palmer et al., 2002; Walker and Pellatt, 2003). These cooler and wetter conditions marked a transition into the Neoglacial period around 3,000 years ago, when conditions allowed significant glacial advance in the region (Whitlock, 1992; Osborn et al., 2012). Thus, during the early Holocene, the Twin Sisters were 
likely warmer and drier than today, with glaciers consequently smaller than today or completely absent, followed by a transition period to cooler and wetter Neoglacial conditions with glacial advance, followed by rapid deglaciation at the end of the Little Ice Age.

Once average snow cover during the period of exposure is estimated, a physical model of cosmic ray shielding by snowpack can be used to calculate average annual degree of bedrock shielding over the period of exposure:

$$
S_{\text {snow }}=\frac{1}{n} \sum_{i=1}^{n} e^{-z_{\text {snow }} * \rho_{\text {snow }} / L}
$$

Where $S_{\text {snow }}$ is the dimensionless shielding correction, $n$ is the number of monthly snowpack measurements, $z_{\text {snow }}$ is the depth of snowpack, $\rho_{\text {snow }}$ is the density of snow in $\mathrm{g} / \mathrm{cm}^{3}$, and $L$ is the attenuation length of cosmic rays in $\mathrm{g} / \mathrm{cm}^{2}$ (Gosse and Phillips, 2001). In this study, snow-water equivalent (SWE) measurements are used for snow depth. SWE is equal to snow depth multiplied by snow density, and thus this equation can be simplified to:

$$
S_{\text {snow }}=\frac{1}{n} \sum_{i=1}^{n} e^{-S W E / L}
$$

where $S W E$ is equal to measured snow-water equivalent in $\mathrm{cm}$. Results of this calculation give average annual snow shielding.

The relationship between production rate, exposure time, and TCN concentration for stable nuclides such as ${ }^{3} \mathrm{He}$ is shown in the following equation:

$$
N=P t
$$

where $N$ is equal to TCN concentration in atoms $/ \mathrm{g}, P$ is equal to production rate in atoms $/ \mathrm{g} / \mathrm{yr}$, and $t$ is exposure time in years (also called the "exposure age"). $N$ is the TCN concentration of nuclides produced at the surface assuming no erosion. This production rate can be refined to account for local scaling factor, and shielding from snow and topography: 


$$
P_{S}=P_{S L H L} * S_{c} * S_{\text {snow }} * S_{\text {topo }}
$$

where $P_{s}$ is the unique sample production rate at the surface in atoms/g/yr, $P_{S L H L}$ is the sea-level high latitude production rate in atoms/g/yr, $S_{c}$ is the scaling factor (dimensionless, based on altitude and latitude), $S_{\text {snow }}$ is the snow shielding factor (dimensionless), and $S_{\text {topo }}$ is the topographic shielding factor (dimensionless). Measured TCN concentration is a function of exposure time as well as depth below surface; production of cosmogenic ${ }^{3} \mathrm{He}$ decreases exponentially with depth below surface (Kurz and Brook, 1994; Gosse and Phillips, 2001; Harbor et al., 2006). Equation (4) only applies at the surface. For depths (d) below the rock surface, the production rate can be calculated with the following equation:

$$
P_{d}=P_{S}\left(e^{-d \rho / L}\right)
$$

where $P_{d}$ is equal to production rate (atoms/g/yr) at depth $(d)$ below the surface in $\mathrm{cm}, L$ is equal to attenuation length in $\mathrm{g} / \mathrm{cm}^{2}$ (approximately $150 \mathrm{~g} / \mathrm{cm}^{2}$ ) (Lal, 1991; Kurz and Brook, 1994; Gosse and Phillips, 2001; Harbor et al., 2006; Martin et al., 2017), and $\rho$ is equal to rock density in $\mathrm{g} / \mathrm{cm}^{3}$. If we rearrange equation (5) to solve for $(d)$, we can calculate depth below surface with the following equation:

$$
d=\frac{-L}{\rho} \ln \left(P_{d} / P_{s}\right)
$$

When using this equation to calculate depth below surface, both $d$ and $P_{d}$ are unknown.

However, $N$ and $t$ must be known for this calculation, and using equation (3) we know that $P_{d}$ is equal to $N / t$, resulting in:

$$
d=\frac{-L}{\rho} \ln \left(N / P_{S} t\right)
$$

This equation can then be used to calculate erosion rate, since progressive erosion will remove surficial rock, increasing the sample depth below the original surface (with no erosion) for a 
given exposure time and TCN concentration (Gosse and Phillips, 2001; Dunai, 2010). For studying glacial erosion, we assume that erosion during exposed (non-glaciated) time is negligible (as indicated by striated bedrock in the Holocene forefield below the Sisters Glacier), and any apparent erosion depth calculated for a given sample is a result of sub-glacial erosion (Figure 3). We also assume that the sample sites were not covered by significant regolith between Pleistocene deglaciation and Holocene glaciation; this assumption is supported by the minimal regolith on bedrock outside the Holocene glacier limits. Thus, with a known (nonglacial) exposure time, known glacial cover time, and measured TCN concentration, the glacial erosion rate can be calculated by dividing the $d$ variable (depth below surface in $\mathrm{cm}$ ) by the period of glacial cover $\left(t_{g}\right)$ in the following equation:

$$
E=\frac{-L}{\rho t_{g}} \ln \left(N / P_{s} t_{e}\right)
$$

where $E$ is equal to erosion rate in $\mathrm{cm} / \mathrm{year}, t_{g}$ is equal to the period of glacier cover in years, and $t_{e}$ is equal to the period of exposure to cosmic rays in years (Lal, 1991; Harbor et al., 2006). This is not a typical "mean erosion rate," but an erosion rate for each individual sample location averaged over the period of glacier cover.

Although terrestrial in-situ cosmogenic ${ }^{3} \mathrm{He}$ production rates are well-known, olivine is also likely to contain ${ }^{3} \mathrm{He}$ inherited from other sources (Amidon and Farley, 2011). Total measured ${ }^{3} \mathrm{He}$ in a given sample is shown with the following equation:

$$
{ }^{3} \mathrm{He}_{\mathrm{m}}={ }^{3} \mathrm{He}_{\mathrm{co}}+{ }^{3} \mathrm{He}_{\mathrm{in}}+{ }^{3} \mathrm{He}_{\mathrm{nu}}+{ }^{3} \mathrm{He}_{\mathrm{mu}}
$$

where ${ }^{3} \mathrm{He}_{\mathrm{m}}$ is the total measured ${ }^{3} \mathrm{He},{ }^{3} \mathrm{He}$ co is cosmogenically-produced, ${ }^{3} \mathrm{He}$ in is the inherited component (from the mantle, distinct from any "inherited" cosmogenic ${ }^{3} \mathrm{He}$ from prior exposure), ${ }^{3} \mathrm{He}_{\mathrm{nu}}$ is the nucleogenic component produced by radioactive decay and ensuing reactions on ${ }^{6} \mathrm{Li}$, and ${ }^{3} \mathrm{He}_{\mathrm{mu}}$ is produced by muons (Amidon and Farley, 2011). To isolate the 
cosmogenic component, it is necessary to remove or account for the inherited, nucleogenic, and muonic ${ }^{3} \mathrm{He}$ (Amidon and Farley, 2011). Inherited ${ }^{3} \mathrm{He}$ is held primarily within melt and fluid inclusions, and can usually be removed during sample processing (Licciardi et al., 1999; Amidon and Farley, 2011). In contrast to ${ }^{10} \mathrm{Be}$ and ${ }^{36} \mathrm{Cl}$, there is no evidence for substantial muonproduced ${ }^{3} \mathrm{He}$ in olivine; for this reason, muon production is ignored in the remainder of this work (Dunai, 2010; Amidon and Farley, 2011). Based on the well-known elemental composition of the Twin Sisters dunite (Ragan, 1963; Onyeagocha, 1978) and the Cretaceous-age emplacement of the Twin Sisters (Ragan, 1963), we can assume that nucleogenic ${ }^{3} \mathrm{He}$ is negligible (Amidon and Farley, 2011). The USGS reference materials DTS-1 and DTS-2 are samples of Twin Sisters dunite for which very detailed geochemistry data are available (Smith, 1995). Using the USGS reference concentrations, the computational model of Amidon et al. (2008) and assuming a ${ }^{3} \mathrm{He}$ accumulation period of $100 \mathrm{Ma}$ (a very conservative upper limit to the exhumation age of the Twin Sisters), the amount of nucleogenic ${ }^{3} \mathrm{He}$ from the reaction ${ }^{6} \mathrm{Li}(\mathrm{n}, \alpha) \mathrm{T} \rightarrow{ }^{3} \mathrm{He}$ present in the dunite is $\sim 6400$ atoms/g. This extraordinarily low nucleogenic ${ }^{3} \mathrm{He}$ concentration arises from the extremely low $\mathrm{U}$ and Th concentration of the dunite, and is orders of magnitude below the measured ${ }^{3} \mathrm{He}$ concentrations in our samples. Additionally, in principle it is possible to isolate the inherited component by measuring ${ }^{3} \mathrm{He}$ in shielded samples with little if any cosmogenic ${ }^{3} \mathrm{He}$, the value of which can then be subtracted from total ${ }^{3} \mathrm{He}$ in exposed samples (Dunai, 2010; Amidon and Farley, 2011). For this study, we assume that the background ${ }^{3} \mathrm{He} /{ }^{4} \mathrm{He}$ ratio measured in shielded samples is consistent throughout the Twin Sisters dunite body, and use measured ${ }^{4} \mathrm{He}$ to calculate the inherited ${ }^{3} \mathrm{He}$ from the mantle.

Some studies have found that several thousand years of Pleistocene glaciation locally did not erode deeply enough to remove all TCNs accumulated prior to the Holocene (e.g., Briner and 
Swanson, 1998; Colgan et al., 2002). Late Pleistocene glaciation inundated the study area for $>15,000-20,000$ years immediately preceding Holocene exposure, and there is abundant evidence that the glaciers were warm-based and sliding (Stelling and Tucker, 2007). Collecting samples outside the limit of Holocene glaciation provides a means to test if Pleistocene glaciation eroded enough bedrock to remove all cosmogenic ${ }^{3} \mathrm{He}$ from prior exposure. Because deglaciation occurred around 11,000 years ago in this area (Clague et al., 1997; Kovanen and Easterbrook, 2001; Menounos et al., 2009), these samples should have an exposure age of approximately 11,000 years if they did not have pre-Pleistocene inheritance. Additionally, none of the samples collected within the Holocene ice limit should return pre-Holocene exposure ages if this assumption is true. By analyzing the pattern of ${ }^{3} \mathrm{He} \mathrm{TCN}$ abundances in the now-exposed glacier forefield, this study provides detailed constraints on the spatial variability of subglacial erosion rates and processes, a variable that has been difficult to constrain by other studies (Crest et al., 2017).

\subsection{Methods}

\subsection{Imagery}

We used recently-acquired Light Detection and Ranging (lidar) data, as well as historic aerial photographs and Google Earth imagery to constrain previous extents of the Twin Sisters glacier following Pleistocene deglaciation. In 2016, a lidar dataset was acquired for Mount Baker and the surrounding area, reaching parts of the Twin Sisters Range, including the study area on the northeastern side of the range (Ramsey, 2016). Using ArcGIS software and the lidar digital elevation model (DEM), we created hillshade images and slope maps to analyze characteristics of the topography. We mapped glacial fluting features (used to determine paleo-ice flow directions), moraine deposits, and a network of bedrock fractures in the forefield of the modern 
glacier (Figure 4). We constrained a likely maximum Neoglacial extent of the Sisters Glacier using bedrock weathering patterns and surface deposits imaged in Google Earth. This technique is based on the assumption that dunite bedrock oxidizes and turns darker in color over time. We estimated a maximum Neoglacial extent along relatively distinct color transitions in addition to rubble deposits visible in Google Earth imagery (Figure 5). We used historical aerial and oblique photographs from 1927, 1940, 1947, 1966, 1972, and 1988 (acquired from the Whatcom Museum, Bellingham, WA, the Center for Pacific Northwest Studies, Western Washington University, and the United States Geological Survey) to map historic extents of the Sisters Glacier (Figure 6). Results of historical photo mapping in combination with lidar and Google Earth imagery analysis are used to constrain the time that the forefield was being eroded by glacial ice.

\subsection{Field work}

In June of 2017, we collected several fully-shielded rock samples from the Sven Larsen dunite quarry along the north slope of the Twin Sisters Range (Figure 7). In August of 2017, we collected exposed rock samples along several transects in the forefield below the Sisters Glacier and mapped glacial features to confirm the remote imagery mapping. We used the Avenza Maps application (www.avenza.com/avenza-maps/) on a smart phone to view a georeferenced lidar hillshade image in the field, allowing us to locate ourselves on the lidar imagery. We used a handheld Garmin GPS unit for navigation and waypoint marking. We noted degree of bedrock oxidation (a qualitative color observation) in order to validate observations of possible glacial erosion indicated in Google Earth imagery. In the glacial forefield, we measured orientations of glacial striae to validate paleo-ice flow directions interpreted from glacial fluting observed in the lidar data (Figure 4). Although bedrock outside the Neoglacial extent limit had smooth and 
hummocky morphology characteristic of glacial scouring, chemical weathering has removed actual striae.

In order to minimize uncertainty from snow cover, and to increase the likelihood that our samples were eroded by glacial ice and not by fluvial or hillslope processes, we preferentially selected sample sites on high ridges with striated surfaces. Rock samples were collected using a sledge hammer and chisel. At each sample location, we recorded latitude, longitude, and elevation. We recorded surface description, thickness of sampled material, any evidence of shielding (soil, vegetation, rubble, etc.), and oxidation rind color and thickness. Using a Brunton compass, we measured surface strike and dip, and horizon angles at eight different azimuths, both of which are used to calculate topographic shielding from cosmic rays. We collected eight samples ("lowland") from outside the Neoglacial extent (six bedrock, two glacial erratics). In the forefield (within the Holocene ice limit), we collected a total of 26 samples along three glacial flow-line transects (Figure 8). Sample sites were selected for prominence (to minimize shielding effects), and presence of glacial striations. We preferentially selected sites with glacial striations because post-glacial erosion (rockfall, fluvial processes, etc.) is very unlikely in these locations. The overall scarcity of sediment deposits in front of the glacier suggest that it is highly unlikely that these sites were covered in sediment. At each site, we took 5-8 photographs of the sample and surrounding topography. Each sample was labeled and placed in a plastic bag for transportation.

\subsection{Sample Processing}

Rock samples were crushed, sieved to 125-500 microns, and washed at Western Washington University. At the Caltech Noble Gas Lab, samples were leached in weak (2\% wt) hydrofluoric acid for 20 minutes to remove grain coatings with atmospheric ${ }^{3} \mathrm{He}$. Next, each 
sample was crushed under ethanol to less than $\sim 30 \mu \mathrm{m}$ diameter in a mortar and pestle, dried, and weighed into a tin foil ball. These tin foil sample balls were loaded into the vacuum system for analysis of ${ }^{3} \mathrm{He}$ and ${ }^{4} \mathrm{He}$ concentrations.

\subsection{Calculations}

In this study, we used a calculation following Kurz (1986) to determine cosmogenic ${ }^{3} \mathrm{He}$ concentrations. For our samples, we know that ${ }^{3} \mathrm{He}_{\mathrm{co}}={ }^{3} \mathrm{He}_{\mathrm{m}}-{ }^{3} \mathrm{He}_{\mathrm{in}}$, following equation (9). To estimate the mantle ${ }^{3} \mathrm{He}$ component, we analyzed the ${ }^{3} \mathrm{He} /{ }^{4} \mathrm{He}$ ratio of cosmic-ray shielded samples and assumed that all ${ }^{4} \mathrm{He}$ is mantle-derived. With a known inherited ${ }^{3} \mathrm{He} /{ }^{4} \mathrm{He}$ ratio, the following equation can be used to calculate cosmogenic ${ }^{3} \mathrm{He}$ :

$$
{ }^{3} \mathrm{He}_{\mathrm{co}}={ }^{3} \mathrm{He}_{\mathrm{m}}-\left({ }^{3} \mathrm{He}_{\text {shielded }} /{ }^{4} \mathrm{He}_{\text {shielded }}\right) *{ }^{4} \mathrm{He}_{\text {shielded }}
$$

where ${ }^{3} \mathrm{He}_{\mathrm{co}}$ is equal to the calculated cosmogenic ${ }^{3} \mathrm{He},{ }^{3} \mathrm{He}_{\mathrm{m}}$ is equal to the measured ${ }^{3} \mathrm{He}$ concentration, and ${ }^{3} \mathrm{He}_{\text {shielded }}$ and ${ }^{4} \mathrm{He}_{\text {shielded }}$ are equal to the ${ }^{3} \mathrm{He}$ and ${ }^{4} \mathrm{He}$ concentrations measured in shielded samples (Kurz, 1986). For each sample, we subtracted mantle ${ }^{3} \mathrm{He}$ based on the range of 1.8 to $2.8 \mathrm{R}_{\mathrm{A}}$ (discussed in results), with an average ratio of $2.3 \mathrm{R}_{\mathrm{A}}$. The assumed variability in the mantle ratio accommodates the observed ratio variability in shielded samples and the resulting ${ }^{3} \mathrm{He}_{\mathrm{c}}$ is a likely range of cosmogenic ${ }^{3} \mathrm{He}$ for each sample, based on data from shielded samples. When measured ${ }^{4} \mathrm{He}$ is high, the resulting range of calculated ${ }^{3} \mathrm{He}_{\mathrm{c}}$ increases. This introduces a significant uncertainty in samples with high ${ }^{4} \mathrm{He}$, such that it is not possible to extract any meaningful information from samples with exceedingly high ${ }^{4} \mathrm{He}$. It was necessary to remove several samples from calculations as a result of this uncertainty (discussed in results). We used the range of calculated ${ }^{3} \mathrm{He}$ in subsequent calculations to model exposure ages and erosion depths. For this calculation, we assume that the mantle ${ }^{3} \mathrm{He} /{ }^{4} \mathrm{He}$ ratio in the Twin Sisters dunite body is homogeneous within the range we measured in the quarry. 
We calculated unique ${ }^{3} \mathrm{He}$ production rate values for each sample site based on location, elevation, topographic shielding, and snow shielding (Equation 4). We used the online Cosmic Ray Exposure Program (CREp) calculator (Martin et al., 2017) to generate a scaling factor value for each sample site, using the Lal-Stone time-corrected scaling scheme (Nishiizumi et al., 1989; Lal, 1991; Stone, 2000; Balco et al., 2008), the Standard Atmosphere model (N.O.A.A., 1976), and the Atmospheric ${ }^{10} \mathrm{Be}$-based VDM Geomagnetic Database (Muscheler et al., 2005). Using a lidar-based DEM on ArcGIS, we generated a horizon angle at azimuths from 0-360 degrees at single degree increments for each sample and took the average for each of eight quadrants $(\mathrm{N}$, NE, E, SE, S, SW, W, and NW). With horizon angle and field-measured surface strike and dip measurements, we used Balco's online topographic shielding calculator to generate a topographic shielding value (from 0 -1, zero being completely shielded by topography and one being completely unshielded) for each sample site (Balco, 2006).

In order to estimate modern snow shielding conditions for the samples, we used data from a DHSVM model run as well as data from nearby SNOTEL sites. We used data from the DHSVM model to estimate monthly average snow water equivalent (SWE) conditions in the study area from 1950-2009. We selected a representative central grid point in the forefield and one in the lowland (Figure 7). We generated snow shielding factors for each point based on monthly averages from the model run using Equation 2. We selected nearby SNOTEL sites that are at similar elevations to sample locations. For lowland samples, we used data from Elbow Lake, Skookum Creek, Alpine Meadows, and Stevens Pass stations. For forefield samples, we used data from MF Nooksack, Wells Creek, Surprise Lakes, and Bumping Ridge stations (Figure 2). Snow water equivalent (SWE) data from these SNOTEL sites are used for this analysis because shielding from snowpack is dependent on density of snowpack (Schildgen et al., 2005). 
From the SNOTEL data, we calculated monthly SWE averages for the length of the record and used these results in Equation (2) to generate a snow shielding factor (based on modern conditions) for each SNOTEL site.

Because climatic conditions were likely significantly warmer/drier during the early and mid-Holocene (Mathewes and Heusser, 1981; Whitlock, 1992; Pellatt et al., 2000; Palmer et al., 2002; Walker and Pellatt, 2003), we reduced SWE estimates by 50\% of modern at each site for the first 9,000 years following Pleistocene deglaciation, and increase them to modern conditions at the lower site for the subsequent 2,000 years of Neoglaciation. At the upper site, we calculated two snow shielding correction end-members based on the range of possible exposure histories. A maximum snow shielding correction scenario results from no Holocene glacier cover, calculated following the method used for lowland samples. We calculate a reasonable minimum snowshielding correction by modeling 9,000 years of SWE cover at $50 \%$ of modern conditions. The $50 \%$ SWE reductions were based on data of Holocene climate fluctuations (discussed in background section). Based on results from SNOTEL sites and DHSVM model run, lowland sample sites and forefield sample sites were assigned different ranges for likely snow shielding scenarios. These ranges were applied in production rate calculations as uncertainties.

Model exposure ages (assuming zero erosion) for each sample were calculated using equations (3) and (4). Periods of exposure and glaciation were estimated for each sample site. Based on records from nearby Mount Baker, all forefield sample sites were likely exposed for a minimum of 9,000 years following Pleistocene deglaciation. With the onset of Neoglaciation, forefield samples had differing lengths of exposure and glaciation due to a series of glacial advances and retreats during this time. Sample sites near the distal edge of the Holocene extent were likely exposed for much of the Neoglaciation ( 2,500 years) and glaciated for less time 
( $\sim 00$ years). Conversely, sample sites near the modern terminus of the glacier likely

experienced about 500 additional years of exposure and 2,500 years of glaciation. Using results from Osborn et al. (2012), we estimated approximate extents of Neoglacial advances in the Twin Sister forefield (Figure 9). Based on location of sample sites relative to Neoglacial extents, we estimated periods of exposure and glaciation for each sample. Because these estimates are necessarily approximate, we assign an error margin of \pm 400 years for each sample. This is a fairly conservative error margin and represents approximately $15 \%$ of the period of Neoglaciation. We used an average density of $3.3 \mathrm{~g} / \mathrm{cm}^{3}$, based on measurements of six samples, for all calculations. We used density measurements, period of glaciation estimates, calculated production rates, and measured cosmogenic ${ }^{3} \mathrm{He}$ with equations (7) and (8) to calculate a likely range of erosion depths and erosion rates for each forefield sample.

\subsection{Results}

\section{$4.1^{3} \mathrm{He}^{4} \mathrm{He}$ ratios}

We were unable to remove mantle ${ }^{3} \mathrm{He}$ from our samples through conventional crushing methods; analyzing different grain size fractions of several exposed samples had no significant effect on ${ }^{3} \mathrm{He}$ concentrations (Figure 10). However, all shielded samples showed air-normalized ${ }^{3} \mathrm{He} /{ }^{4} \mathrm{He}$ ratios that ranged from 1.69 to $3.72 \mathrm{R}_{\mathrm{A}}$, with the majority around 2.3 to $2.5 \mathrm{R}_{\mathrm{A}}$ and an average of $2.3 \mathrm{R}_{\mathrm{A}}\left(\mathrm{r}^{2}=0.89\right.$, Figure 11$)$. The only accessible site for collecting fully shielded samples was at the Sven Larsen Quarry (Figure 7), and there are no data about mantle ${ }^{3} \mathrm{He} /{ }^{4} \mathrm{He}$ ratios throughout the Twin Sisters dunite body. Thus, for this study, we must assume that mantle ${ }^{3} \mathrm{He} /{ }^{4} \mathrm{He}$ ratios are consistent between the Sven Larsen Quarry and the main study area.

Exposed samples showed significant variance in measured ${ }^{3} \mathrm{He} /{ }^{4} \mathrm{He}$ ratios, indicating large differences in cosmogenic ${ }^{3} \mathrm{He}$ concentrations among samples. Lowland sample ${ }^{3} \mathrm{He} /{ }^{4} \mathrm{He}$ 
ratios ranged from 1.9 to $27.1 \mathrm{R}_{\mathrm{A}}$, and forefield sample ${ }^{3} \mathrm{He} /{ }^{4} \mathrm{He}$ ratios ranged from 1.48 to 41.7 $\mathrm{R}_{\mathrm{A}}$, with low ratios (those similar to shielded samples) indicating zero cosmogenic ${ }^{3} \mathrm{He}$, and higher ratios indicating greater cosmogenic ${ }^{3} \mathrm{He}$ (Table 1).

\subsection{Snow Shielding}

Results from DHSVM and SNOTEL analyses suggest a wide range of potential snowshielding conditions for both lowland and forefield samples. Because of the higher elevation, forefield sample sites require a higher snow-shielding correction (0.67-0.93, mean of 0.82$)$ than lowland sample sites $(0.85-0.98$, mean of 0.91$)$, which is reflected in the snow shielding results (Table 2).

\subsection{Model Exposure Ages}

Model exposure ages (calculated with Equations 3 and 11) for all samples showed significant variation in both forefield and lowland samples. Many samples had exceedingly high concentrations of presumably mantle-derived ${ }^{4} \mathrm{He}(>40 \mathrm{ncc} / \mathrm{g}$, Table 1$)$, and thus high uncertainties in corrected cosmogenic ${ }^{3} \mathrm{He}$. This large uncertainty resulted in model exposure age ranges that are too large to produce meaningful results. We therefore removed any analyses with $>40 \mathrm{ncc} / \mathrm{g}{ }^{4} \mathrm{He}$ (model exposure age uncertainties greater than $\pm 1,500$ years before accounting for snow shielding, Table 1). After accounting for uncertainties related to snow shielding and background ${ }^{3} \mathrm{He} /{ }^{4} \mathrm{He}$ ratios, the remaining lowland samples produced model exposure ages ranging from $7,800 \pm 800$ to $21,500 \pm 2,600$ (Figure 12, Table 3), and remaining forefield samples produced model exposure ages ranging from $0 \pm 900$ to 10,500 \pm 1,900 (Figure 13, Table 3). Uncertainties in these results reflect uncertainties in both background ${ }^{3} \mathrm{He} /{ }^{4} \mathrm{He}$ ratio and snow shielding. Although there is a $\sim 3 \%$ analytic uncertainty, this uncertainty is insignificant compared to other sources of uncertainty, and can thus be ignored. 
Despite the substantial uncertainties, two interesting trends are evident: 1) model exposure ages in lowland samples are generally much older than forefield samples, and 2) model exposure ages of forefield samples tend to decrease with proximity to the modern glacier (Figure 13). Samples in the westernmost transect of the forefield show the latter trend particularly well, especially in the mean model ages. Samples in the easternmost transect of the forefield also show the trend, but with greater variability near the edge of the Holocene limit. There are not enough meaningful analyses in the central transect to discern any trends. For examination of correlations between exposure age, erosion depths and rates and distance from the modern glacier along glacial flow-lines, it is reasonable to ignore uncertainty related to snow shielding and period of glacier cover. Although these uncertainties greatly increase uncertainty in absolute exposure ages, and erosion depths and rates, it is unlikely that snow and glacial conditions among adjacent forefield samples would have varied dramatically, since all samples experienced the same climatic conditions during the Holocene (Figure 13). Including all forefield samples, there is a correlation between calculated exposure age and distance from modern glacier along glacial flow-lines $\left(r^{2}=0.59\right.$, Figure 13). Two outliers (T1S7 and T2S1) show younger ages than would be expected based on this trend. When these outliers are removed from the regression, significance increases dramatically $\left(r^{2}=0.86\right.$, Figure 13).

\subsection{Erosion Depths and Rates}

Patterns of modeled erosion depths and rates show a roughly inverse trend to that of exposure ages. Depth of apparent erosion tends to increase with proximity to the modern glacier (Figure 14), and varies from $0.15 \mathrm{~cm}$ to $146 \mathrm{~cm}$. There is a possible correlation between erosion depth and distance from the modern glacier along glacial flow-lines $\left(r^{2}=0.51\right.$, Figure 14). When outliers (T1S7 and T2S1) are removed, the significance of the correlation increases moderately 
$\left(r^{2}=0.62\right.$, Figure 14). Accounting for uncertainties related to mantle ${ }^{3} \mathrm{He}$, snow shielding, and period of glaciation, rates of erosion show a similar trend (Figure 15), spanning two orders of magnitude from $0.001 \mathrm{~mm} / \mathrm{yr}$ farthest from the glacier to $0.7 \mathrm{~mm} / \mathrm{yr}$ directly adjacent to the glacier. Although this trend may be detectable visually, there is no apparent correlation between erosion rate and distance from the modern glacier along glacial flow-lines $\left(\mathrm{r}^{2}=0.20\right.$, Figure 15$)$. When outliers (T1S7 and T2S1) are removed, this correlation increases moderately but is still insignificant $\left(\mathrm{r}^{2}=0.48\right)$.

\subsection{Discussion}

\subsection{Mantle Inheritance}

Relatively consistent ${ }^{3} \mathrm{He}$ concentrations in exposed samples analyzed at different grain size fractions (Figure 10) indicate that the traditional crushing method used to remove mantleinherited ${ }^{3} \mathrm{He}$ (e.g., Kurz, 1986) was not successful in our samples because the melt or fluid inclusions where such helium is typically held are apparently much smaller in twin sisters dunite than in more commonly studied olivine phenocrsyts. We therefore elected to process our samples at an extra-fine (less than $\sim 30 \mu \mathrm{m}$ ) grain size in order to minimize potential mantle-inherited ${ }^{3} \mathrm{He}$, and isolated cosmogenic ${ }^{3} \mathrm{He}$ through calculations following sample analyses (Equation 11). A step-heating experiment undertaken on one Twin Sisters dunite sample indicated that mantleinherited ${ }^{3} \mathrm{He}$ may diffuse out of the olivine crystals at a higher temperature than cosmogenic ${ }^{3} \mathrm{He}$, and thus future studies could involve stepwise heating of samples to more directly isolate cosmogenic ${ }^{3} \mathrm{He}$ (Farley, 2018, personal communication).

In shielded samples, ${ }^{3} \mathrm{He} /{ }^{4} \mathrm{He}$ ratios varied from approximately 1.8 to 2.8 , and this variance in ${ }^{3} \mathrm{He} /{ }^{4} \mathrm{He}$ ratios produced significant uncertainties in results when used to calculate cosmogenic ${ }^{3} \mathrm{He}$ concentrations in many of our samples. For this study, we assume that 
background ${ }^{3} \mathrm{He} /{ }^{4} \mathrm{He}$ ratios remains constant throughout the Twin Sisters dunite body, in particular that it is consistent between the Sven Larsen Quarry (our only site for demonstrably shielded samples) and our field sample sites, but this assumption remains untested. In order to test this assumption, it will be necessary to collect shielded samples from a variety of different locations in the range. We also plan to refine the results of this study by crushing each sample in a vacuum and measuring ${ }^{3} \mathrm{He}$ and ${ }^{4} \mathrm{He}$ before and after the crush (following Kurz (1986)). This will allow us to generate a unique ${ }^{3} \mathrm{He} /{ }^{4} \mathrm{He}$ inherited component correction for each sample, rather than using a blanket ${ }^{3} \mathrm{He} /{ }^{4} \mathrm{He}$ correction based on analyses of cosmic-ray shielded samples.

\subsection{Erosional Patterns}

Our results show distinct patterns in the spatial variation of Holocene cirque-glacial erosion beneath the Sisters Glacier. Theoretical models predict that magnitude and rate of subglacial erosion should increase with increasing sliding velocity and ice thickness (Hallet, 1996; Glasser and Bennett, 2004; Iverson, 2012; Herman et al., 2015). Our ${ }^{3} \mathrm{He}$ analyses showing progressively greater rates and magnitudes of erosion up-glacier are broadly consistent with these models; ice thickness of the Sisters Glacier certainly would have increased from the terminus towards the accumulation zone during maximum Neoglaciation; similarly, because the slope of the Holocene forefield is relatively constant, sliding velocities also should have increased with increased ice thickness and proximity to the glacier equilibrium line. Additionally, samples closer to the modern glacier were almost certainly glaciated for a longer time period, which would increase the magnitude of subglacial erosion. Although our data show increasing depths of erosion with proximity to the modern glacier, the pattern of increasing rates of erosion with proximity to the modern glacier is indistinct. Since erosion depth and erosion rate calculations both rely on known periods of exposure and erosion, uncertainties in these periods 
can amplify apparent trends in results. An independent age control is necessary to minimize this uncertainty, and could potentially be done in the future with measurements of two cosmogenic isotopes (at least one radioactive) rather than one (e.g., Corbett et al., 2016).

The broad pattern of low and progressively increasing depths and rates of erosion upglacier suggests that abrasion is a dominant erosional mechanism in the Sisters Glacier. If quarrying was a dominant erosional mechanism, we would expect more spatially heterogeneous depths and rates of erosion. An abrasion-dominated environment is consistent with Herman et al. (2015), who suggest that abrasion may dominate over quarrying underneath warm-based steep glaciers due to subglacial water and steep slopes promoting rapid sliding velocities. Studies in Yosemite National Park, USA, concluded that spacing of bedrock fracture zones are the primary control on rates of glacial erosion, with more heavily fractured bedrock resulting in more rapid erosion, presumably related to enhanced quarrying (Duhnforth et al., 2010; Becker et al., 2014). The pervasive nature of fractures in the bedrock in the Sisters Glacier cirque would seem to make it particularly susceptible to glacial quarrying; however, our data do not show clear evidence of spatially heterogeneous erosion that would be more indicative of glacial quarrying. Detailed quantitative analyses of fracture spacing relative to sample locations in the Twin Sisters Holocene forefield would be needed to further assess this possibility. Although there is a broad trend of increasing depths and rates of erosion with proximity to the modern glacier, two samples (T1S7 and T2S1) show anomalously high magnitudes and rates of erosion relative to other nearby samples (Figures 14 and 15). This result suggests that these samples either experienced a higher degree of abrasion, or were quarried by the Sisters Glacier. We found it useful to ignore these samples when examining correlations between distance from the modern glacier and exposure age, erosion depth, and erosion rate. Samples T1S7 and T2S1 do not fit the pattern of 
consistently increasing exposure ages, erosion depths, and erosion rates that is seen in other samples. Erosion depths in T1S7 and T2S1 are more than $15 \mathrm{~cm}$ (and up to $35 \mathrm{~cm}$ ) greater than adjacent samples, showing a pattern that suggest erosion by glacial quarrying. It is useful to remove these samples from the regression to examine correlations among only presumed abraded samples. After removing these outliers from regression, significance of the correlation increases in all three results (exposure age, erosion depth, and erosion rate, Figures 13, 14, and 15). Overall, our data show that the Twin Sisters glacial forefield was primarily eroded by abrasion, with the potential for small, spatially consistent quarrying events (centimeters to decimeters in depth).

When erosion depth is approximately equal to or greater than the depth of cosmic ray penetration, accuracy of erosion calculations decreases significantly. Two samples, T3S1 and T1S2, returned model exposure ages of approximately zero ( 0 and 400, with maximum ages of 900 and 1,400, respectively, within uncertainty), indicating high erosion depths $(\geq 1.4 \mathrm{~m})$ and rates $(\geq 0.7 \mathrm{~mm} / \mathrm{yr})$. T3S1 was located on the top of a prominent bedrock ridge with a striated surface. We would not expect such an apparently resistant ridge to have experienced this high degree of erosion. Based on this finding, this sample site either experienced rapid subglacial abrasion ( $\geq 0.7 \mathrm{~mm} / \mathrm{yr}$ ), or was quarried by the Sisters Glacier. Sample T1S2 was not striated, and located on what appeared to be a steep quarrying front, an approximately vertical surface downglacier from a more shallowly-inclined, striated surface. Given these characteristics, it would be reasonable for T1S2 to have experienced a high erosion rate, possibly related to the passing of a quarrying front, but because the sample site was not striated, we cannot rule out that some of the calculated erosion may relate to hillslope failure. Because both of these samples have no detectable cosmogenic ${ }^{3} \mathrm{He}$, our estimates for total erosion and erosion rates are minima. 
Overall, our estimated rates of erosion $(0.001 \mathrm{~mm} / \mathrm{yr}$ to $0.7 \mathrm{~mm} / \mathrm{yr})$ fall within ranges of cirque-glacial erosion found in previous studies. Most studies of cirque-glacier erosion have found rates consistent with the upper limit of our findings (e.g., Reheis, 1975; Larsen and Mangerud, 1981; Bogen, 1996; Brook et al., 2006; Sanders et al., 2013), whereas our lower limit is more consistent with cirque-glaciers in arctic regions (e.g., Anderson, 1978; Bennett et al., 1999). However, measurements from other studies are averages for basin-wide erosion, whereas ours focuses on erosion rates at discrete locations. It is possible, although unlikely, that our sampling missed major zones of subglacial erosion; conversely, studies of basin-wide averages may inadvertently include non-subglacial sources of sediment (e.g., rock fall, overridden debris, etc.) Our calculated erosion rates are also significantly lower than subglacial erosion rates beneath temperate valley glaciers, typically up to $10 \mathrm{~mm} / \mathrm{yr}$ (Riihimaki, 2005; Sanders et al., 2013; Herman et al., 2015; Koppes et al., 2015). Instead, our findings suggest that despite the relatively steep slopes of the Sisters Glacier forefield as well as the pervasive fracturing of the bedrock, the ice was too thin during Neoglaciation to produce the rapid sliding velocities and high basal shear stress necessary to produce high erosion rates.

Different methods of measuring glacial erosion rates can over- or under-estimate subglacial erosion, making it difficult to compare results among differing methods. Delmas et al. (2009) suggests that TCN techniques are more likely to underestimate modeled erosion rates than other commonly-used sediment-volume methods; accuracy of TCN calculations is low when erosion rates are high because cosmic rays can only penetrate a few meters into the rock surface, and leading to consistent reporting of lower erosion rates from TCN techniques (Delmas et al., 2009). In our study, only two samples (T1S2 and T3S1) show results that suggest Holocene erosion possibility greater than $1.4 \mathrm{~m}$ in depth. With the exception of T1S2 and T3S1, 
the presence of cosmogenic ${ }^{3} \mathrm{He}$ in all other samples indicates that less than 1.4 meters of rock was removed during Neoglaciation. It is possible that the depths of erosion at T1S2 and T3S1 is actually significantly greater than $1.4 \mathrm{~m}$, in which case the average erosion rate based on all samples would be a minimum. Erosion rate estimates calculated from sediment volume can overestimate subglacial erosion due to multiple sources of sediment (Delmas et al., 2009), and other studies have also observed large changes in glacial sediment yield year to year, suggesting that changes in precipitation and glacial drainage systems control sediment yield more than subglacial erosion (Hicks et al., 1990; Bogen, 1996). When these studies are conducted over short timescales (typically years), results may not accurately represent long-term average erosion rates. Our results clearly reflect erosion rates averaged over an entire glacial period (Neoglaciation, 2,000 yr locally), but may not reflect basin-wide average glacial erosion rates.

\subsection{Holocene Glacial Extents}

Our estimates of timing and extent of Holocene glacial cover in the cirque, based on correlation to glaciers on Mt. Baker, introduce a finite but still uncertain amount of error (Figure 9). We cannot rule out the possibility that the Sisters Glacier behaved differently from Mt. Baker glaciers during the Neoglacial advances and retreats. In our calculations, we included a fairly conservative uncertainty surrounding our estimated periods of exposure and glaciation $( \pm 400$ years, see Calculations section). If we consider two extreme scenarios, 1) where the forefield was completely glaciated for the entirety of the Neoglacial period, and 2) where the forefield was only glaciated during the final 300 years of Neoglaciation, we still see the same patterns discussed in section 5.2. However, the calculated erosion rates span an order of magnitude for each sample between these two extreme scenarios; most notably, samples nearest to the modern glacier could have eroded the bedrock as fast as $5 \mathrm{~mm} / \mathrm{yr}$ if they only experienced 300 years of 
glacier cover during Neoglaciation. These scenarios remain highly unlikely, but cannot be ruled out for this study.

\subsection{Inheritance from Prior Exposure}

The wide range of exposure ages for the lowland samples outside the Neoglacial ice limits, suggests that our initial assumption of zero inheritance from prior exposure may not be valid, at least locally. Two samples, LL4 and LL5 (exposure ages 18,700 and 21,500, respectively), show evidence of inheritance of cosmogenic ${ }^{3} \mathrm{He}$ from prior exposure. Samples LL1 and LL3 (exposure ages 13,800 and 11,900, respectively) returned model exposure ages approximately consistent with independent estimates of Pleistocene deglaciation, and samples LL6 and LL8 (exposure ages 7,800 and 8,000, respectively) show model exposure ages younger than would be expected (Table 3). The younger samples may simply reflect unaccounted for shielding by now-removed sediment; the samples showing apparent exposure inheritance are a bigger concern for our study, though, because they violate our assumption that all bedrock in the study area was eroded deeply enough to reset the cosmogenic clock ( $>1.4 \mathrm{~m}$ of pre-Holocene erosion). The reason for lack of complete resetting in two of the lowland sites is unclear, but may relate to particularly resistant outcrops or low local sliding rates during late-Pleistocene ice-sheet inundation. Regardless of the reason, however, our results suggest that inheritance is not likely to be a significant problem for the forefield samples (within the Holocene ice limits). If the forefield samples contained significant cosmogenic ${ }^{3} \mathrm{He}$ from pre-Pleistocene exposure, we would anticipate that at least some of the forefield samples, particularly those near the Holocene ice limit that experienced minimal erosion, should have returned exposure ages older than Pleistocene deglaciation. The oldest exposure age in our forefield samples is $10,500 \pm 1,900$, which is approximately consistent with the timing of Pleistocene deglaciation. 


\subsection{Sampling Bias}

As discussed in our methodology, we preferentially collected striated samples from ridges in order to guarantee the last erosion was from glacial scour and to minimize the effects of snow cover. Because striations directly reflect subglacial abrasion, it is possible that this sampling method is biased towards surfaces dominantly eroded by abrasion rather than glacial quarrying. Glaciated bedrock is eroded by both abrasion and quarrying (Anderson, 2014), and thus selecting sample sites that were most recently subjected to abrasion would not be biased towards surfaces that were only abraded. Similarly, if quarrying was largely restricted to troughs and abrasion to ridges, we would expect a net growth in relief with progressive erosion. Analyses of the lidar DEMs, however indicates no significant difference in ridge-trough relief between sites higher or lower in the forefield. Quarrying processes are largely controlled by bedrock fracture spacing (Duhnforth et al., 2010; Anderson, 2014), and it follows that dominance of abrasion vs. quarrying may vary in a more predictable way based on that characteristic. We did not collect detailed observations on fracture spacing and orientations for this study, but it may be a fruitful avenue for future study. Overall, although our sampling strategy may have resulted in preferential selection of dominantly abraded samples, we have no distinct evidence that this is the case.

\subsection{Conclusions}

Our analyses of cosmogenic ${ }^{3} \mathrm{He}$ in glaciated bedrock below the Sisters Glacier support several distinct conclusions: 1) the Sisters Glacier experienced steadily greater depths and rates of Holocene subglacial erosion with proximity to the modern glacier; 2) this pattern is consistent with predictions of theoretical models of glacier erosion rates (thicker, faster ice towards the equilibrium line should erode faster); 3) the rates of erosion we document are similar to but at the 
low end of previous studies of basin-wide glacial erosion rates; 4) the regularity of the pattern of erosion suggests that abrasion dominates over quarrying for this glacier, at least during Neoglaciation; 5) shielding of cosmic rays related to snow and ice cover represent an underconstrained source of uncertainty in this and most similar TCN glacial erosion studies, and 6) significant analytic geochemical complexity in our sample suite appears to reflect previously unrecognized behavior of ${ }^{3} \mathrm{He}$ in dunite bedrock possibly related to effects of inherited mantle components. Further studies into Holocene climate and glaciation as well as ${ }^{3} \mathrm{He}$ movement and residence in dunite would substantially improve our results and those of future studies. 


\subsection{References}

Amidon, W.H., and Farley, K.A., 2011, Cosmogenic 3He production rates in apatite, zircon and pyroxene inferred from Bonneville flood erosional surfaces: Quaternary Geochronology, v. 6, p. 10-21, doi:10.1016/j.quageo.2010.03.005.

Amidon, W.H., Farley, K.A., Burbank, D.W., and Pratt-Sitaula, B., 2008, Anomalous cosmogenic 3He production and elevation scaling in the high Himalaya: Earth and Planetary Science Letters, v. 265, p. 287-301, doi:10.1016/j.eps1.2007.10.022.

Anderson, L.W., 1978, Cirque Glacier Erosion Rates and Characteristics of Neoglacial Tills, Pangnirtung Fiord Area, Baffin Island, N.W.T., Canada: Arctic and Alpine Research, v. 10, p. 749, doi:10.2307/1550741.

Anderson, R.S., 2014, Evolution of lumpy glacial landscapes: Geology, v. 42, p. 679-682, doi:10.1130/G35537.1.

Armstrong, J.E., Crandell, D.R., Easterbrook, D.J., and Noble, J.B., 1965, Late Pleistocene Stratigraphy and Chronology in Southwestern British Columbia and Northwestern Washington: Geological Society of America Bulletin, v. 76, p. 321, doi:10.1130/00167606(1965)76[321:LPSACI]2.0.CO;2.

Balco, G., 2006, Geometric Shielding Calculator: CRONUS Earth Online Calculators, http://hess.ess.washington.edu/math/general/skyline_input.php.

Balco, G., Stone, J.O., Lifton, N.A., and Dunai, T.J., 2008, A complete and easily accessible means of calculating surface exposure ages or erosion rates from $10 \mathrm{Be}$ and $26 \mathrm{Al}$ measurements: Quaternary Geochronology, v. 3, p. 174-195, doi:10.1016/j.quageo.2007.12.001.

Barr, I.D., and Spagnolo, M., 2015, Glacial cirques as palaeoenvironmental indicators: Their potential and limitations: Earth-Science Reviews, v. 151, p. 48-78, doi:10.1016/j.earscirev.2015.10.004.

Becker, R.A., Tikoff, B., Riley, P.R., and Iverson, N.R., 2014, Preexisting fractures and the formation of an iconic American landscape: Tuolumne Meadows, Yosemite National Park, USA: GSA Today, v. 24, p. 4-10, doi:10.1130/GSATG203A.1.

Belknap, S.M., 2009, Investigating Processes of Glacial Erosion and Cirque Formation by Numerical Modeling and Field Observations in the Southern Sierra Nevada, California: University of North Carolina.

Bennett, M.R., Huddart, D., and Glasser, N.F., 1999, Large-Scale Bedrock Displacement by Cirque Glaciers: Arctic, Antarctic, and Alpine Research, v. 31, p. 99, doi:10.2307/1552627.

Bogen, J., 1996, Erosion rates and sediment yields of glaciers: Annals of Glaciology, v. 22, p. 48-52, doi:10.3189/1996AoG22-1-48-52.

Booth, D.B., Troost, K.G., Clague, J.J., and Waitt, R.B., 2003, The Cordilleran Ice Sheet, in Developments in Quaternary Sciences, Elsevier, v. 1, p. 17-43, http://linkinghub.elsevier.com/retrieve/pii/S1571086603010029 (accessed June 2017).

Briner, J.P., and Swanson, T.W., 1998, Using inherited cosmogenic 36Cl to constrain glacial erosion rates of the Cordilleran ice sheet: Geology, v. 26, p. 3, doi:10.1130/00917613(1998)026<0003:UICCTC>2.3.CO;2.

Brook, M.S., Kirkbride, M.P., and Brock, B.W., 2006, Cirque development in a steadily uplifting range: rates of erosion and long-term morphometric change in alpine cirques in the Ben Ohau Range, New Zealand: Earth Surface Processes and Landforms, v. 31, p. 1167-1175, doi:10.1002/esp.1327.

Cerling, T.E., and Craig, H., 1994, Cosmogenic $3 \mathrm{He}$ production rates from $39^{\circ} \mathrm{N}$ to $46^{\circ} \mathrm{N}$ latitude, western USA and France: Geochimica et Cosmochimica Acta, v. 58, p. 249-255, doi:10.1016/0016-7037(94)90462-6.

Christensen, N.I., 1971, Fabric, Seismic Anisotropy, and Tectonic History of the Twin Sisters Dunite, Washington: Geological Society of America Bulletin, v. 82, p. 1681-1694, doi:10.1130/00167606(1971)82[1681:FSAATH]2.0.CO;2. 
Clague, J.J., and Mathewes, R.W., 1989, Early Holocene thermal maximum in western North America: New evidence from Castle Peak, British Columbia: Geology, v. 17, p. 277-280, doi:10.1130/0091-7613(1989)017<0277:EHTMIW>2.3.CO;2.

Clague, J.J., Mathewes, R.W., Guilbault, J.-P., Hutchinson, I., and Ricketts, B.D., 1997, Pre-Younger Dryas resurgence of the southwestern margin of the Cordilleran ice sheet, British Columbia, Canada: Boreas, v. 26, p. 261-278, doi:10.1111/j.1502-3885.1997.tb00855.x.

Clark, D.H., and Steig, E.J., 2008, A New Interpretation for Latest Pleistocene Ice Dynamics of the Puget Lobe, Northwest Washington, in Geological Society of America Abstracts with Programs, v. 40, No. 6, p. 219.

Colgan, P.M., Bierman, P.R., Mickelson, D.M., and Caffee, M., 2002, Variation in glacial erosion near the southern margin of the Laurentide Ice Sheet, south-central Wisconsin, USA: Implications for cosmogenic dating of glacial terrains: Geological Society of America Bulletin, v. 114, p. 15811591, doi:10.1130/0016-7606(2002)114<1581:VIGENT>2.0.CO;2.

Corbett, L.B., Bierman, P.R., and Davis, P.T., 2016, Glacial history and landscape evolution of southern Cumberland Peninsula, Baffin Island, Canada, constrained by cosmogenic ${ }^{10} \mathrm{Be}$ and ${ }^{26} \mathrm{Al}$ : Geological Society of America Bulletin, v. 128, p. 1173-1192, doi:10.1130/B31402.1.

Crest, Y., Delmas, M., Braucher, R., Gunnell, Y., and Calvet, M., 2017, Cirques have growth spurts during deglacial and interglacial periods: Evidence from $10 \mathrm{Be}$ and $26 \mathrm{Al}$ nuclide inventories in the central and eastern Pyrenees: Geomorphology, v. 278, p. 60-77, doi:10.1016/j.geomorph.2016.10.035.

Delmas, M., Calvet, M., and Gunnell, Y., 2009, Variability of Quaternary glacial erosion rates - A global perspective with special reference to the Eastern Pyrenees: Quaternary Science Reviews, v. 28, p. 484-498, doi:10.1016/j.quascirev.2008.11.006.

Dick, K., 2013, Glacier Change in the North Cascades, Washington: 1900-2009: Portland State University.

Duhnforth, M., Anderson, R.S., Ward, D., and Stock, G.M., 2010, Bedrock fracture control of glacial erosion processes and rates: Geology, v. 38, p. 423-426, doi:10.1130/G30576.1.

Dunai, T.J., 2010, Cosmogenic nuclides: principles, concepts and applications in the earth surface sciences: Cambridge; New York, Cambridge University Press, http://dx.doi.org/10.1017/CBO9780511804519 (accessed November 2016).

Dunai, T.J., and Wijbrans, J.R., 2000, Long-term cosmogenic 3He production rates (152 ka-1.35 Ma) from 40Ar/39Ar dated basalt flows at $29^{\circ} \mathrm{N}$ latitude: Earth and Planetary Science Letters, v. 176, p. 147-156, doi:10.1016/S0012-821X(99)00308-8.

Easterbrook, D.J., 1969, Pleistocene Chronology of the Puget Lowland and San Juan Islands, Washington: Geological Society of America Bulletin, v. 80, p. 2273, doi:10.1130/00167606(1969)80[2273:PCOTPL]2.0.CO;2.

Fabel, D., Harbor, J., Dahms, D., James, A., Elmore, D., Horn, L., Daley, K., and Steele, C., 2004, Spatial Patterns of Glacial Erosion at a Valley Scale Derived From Terrestrial Cosmogenic ${ }^{10} \mathrm{Be}$ and ${ }^{26}$ Al Concentrations in Rock: Annals of the Association of American Geographers, v. 94, p. 241255, doi:10.1111/j.1467-8306.2004.09402001.x.

Glasser, N.F., and Bennett, M.R., 2004, Glacial erosional landforms: origins and significance for palaeoglaciology: Progress in Physical Geography, v. 28, p. 43-75, doi:10.1191/0309133304pp401ra.

Goehring, B.M., Kurz, M.D., Balco, G., Schaefer, J.M., Licciardi, J., and Lifton, N., 2010, A reevaluation of in situ cosmogenic 3He production rates: Quaternary Geochronology, v. 5, p. 410-418, doi:10.1016/j.quageo.2010.03.001.

Gosse, J.C., and Phillips, F.M., 2001, Terrestrial in situ cosmogenic nuclides: theory and application: Quaternary Science Reviews, v. 20, p. 1475-1560.

Hallet, B., 1996, Glacial Quarrying: A Simple Theoretical Model: Annals of Glaciology, v. 22, p. 1-8.

Harbor, J., Stroeven, A.P., Fabel, D., Clarhäll, A., Kleman, J., Li, Y., Elmore, D., and Fink, D., 2006, Cosmogenic nuclide evidence for minimal erosion across two subglacial sliding boundaries of the 
late glacial Fennoscandian ice sheet: Geomorphology, v. 75, p. 90-99, doi:10.1016/j.geomorph.2004.09.036.

Harper, J.T., 1993, Glacier Terminus Fluctuations on Mount Baker, Washington, U.S.A., 1940-1990, and Climatic Variations: Arctic and Alpine Research, v. 25, p. 332, doi:10.2307/1551916.

Heineke, C., Niedermann, S., Hetzel, R., and Akal, C., 2016, Surface exposure dating of Holocene basalt flows and cinder cones in the Kula volcanic field (Western Turkey) using cosmogenic $3 \mathrm{He}$ and 10Be: Quaternary Geochronology, v. 34, p. 81-91, doi:10.1016/j.quageo.2016.04.004.

Heisinger, B., Lal, D., Jull, A.J.T., Kubik, P., Ivy-Ochs, S., Knie, K., and Nolte, E., 2002, Production of selected cosmogenic radionuclides by muons: 2. Capture of negative muons: Earth and Planetary Science Letters, v. 200, p. 357-369, doi:10.1016/S0012-821X(02)00641-6.

Herman, F., Beyssac, O., Brughelli, M., Lane, S.N., Leprince, S., Adatte, T., Lin, J.Y., Avouac, J.-P., and Cox, S.C., 2015, Erosion by an Alpine glacier: Science, v. 350, p. 193-195.

Heusser, C., Heusser, L., and Peteet, D., 1985, Late Quaternary climate change on the American North Pacific Coast: v. 315.

Hicks, D.M., McSaveney, M.J., and Chinn, T.J.H., 1990, Sedimentation in Proglacial Ivory Lake, Southern Alps, New Zealand: Arctic and Alpine Research, v. 22, p. 26-42, doi:10.2307/1551718.

Iverson, N.R., 2012, A theory of glacial quarrying for landscape evolution models: Geology, v. 40, p. 679-682, doi:10.1130/G33079.1.

Ivy-Ochs, S., Schluchter, C., Kubik, P.W., and Denton, G.H., 1999, Moraine Exposure Dates Imply Synchronous Younger Dryas Glacier Advances in the European Alps and in the Southern Alps of New Zealand: Geografiska Annaler, Series A: Physical Geography, v. 81, p. 313-323, doi:10.1111/1468-0459.00060.

Koppes, M., Hallet, B., Rignot, E., Mouginot, J., Wellner, J.S., and Boldt, K., 2015, Observed latitudinal variations in erosion as a function of glacier dynamics: Nature, v. 526, p. 100-103, doi:10.1038/nature15385.

Kovanen, D.J., and Easterbrook, D.J., 2001, Late Pleistocene, post-Vashon, alpine glaciation of the Nooksack drainage, North Cascades, Washington: Geological Society of America Bulletin, v. 113, p. 274-288, doi:10.1130/0016-7606(2001)113<0274:LPPVAG>2.0.CO;2.

Kurz, M.D., 1986, In situ production of terrestrial cosmogenic helium and some applications to geochronology: Geochimica et Cosmochimica Acta, v. 50, p. 2855-2862, doi:10.1016/00167037(86)90232-2.

Kurz, M.D., and Brook, E.J., 1994, Surface Exposure Dating with Cosmogenic Nuclides, in Dating in Exposed and Surface Contexts, Albuquerque, University of New Mexico Press, p. 139-159.

Lal, D., 1991, Cosmic ray labeling of erosion surfaces: in situ nuclide production rates and erosion models: Earth and Planetary Science Letters, v. 104, p. 424-439, doi:10.1016/0012821X(91)90220-C.

Lal, D., 1998, Cosmic ray produced isotopes in terrestrial systems: Proceedings of the Indian Academy of Sciences (Earth and Planetary Science), v. 107, p. 241-250, doi:10.1007/BF02841592.

Larsen, E., and Mangerud, J., 1981, Erosion Rate of a Younger Dryas Cirque Glacier at Krakenes, Western Norway: Annals of Glaciology, v. 2, p. 153-158.

Licciardi, J.M., Kurz, M.D., Clark, P.U., and Brook, E.J., 1999, Calibration of cosmogenic $3 \mathrm{He}$ production rates from Holocene lava flows in Oregon, USA, and effects of the Earth's magnetic field: Earth and Planetary Science Letters, v. 172, p. 261-271.

Martin, L.C.P., Blard, P.-H., Balco, G., Lavé, J., Delunel, R., Lifton, N., and Laurent, V., 2017, The CREp program and the ICE-D production rate calibration database: A fully parameterizable and updated online tool to compute cosmic-ray exposure ages: Quaternary Geochronology, v. 38, p. 25-49, doi:10.1016/j.quageo.2016.11.006.

Mathewes, R.W., and Heusser, L.E., 1981, A 12000 year palynological record of temperature and precipitation trends in southwestern British Columbia: Canadian Journal of Botany, v. 59, p. $707-$ 710, doi:10.1139/b81-100. 
Menounos, B., Osborn, G., Clague, J.J., and Luckman, B.H., 2009, Latest Pleistocene and Holocene glacier fluctuations in western Canada: Quaternary Science Reviews, v. 28, p. 2049-2074, doi:10.1016/j.quascirev.2008.10.018.

Muscheler, R., Beer, J., Kubik, P.W., and Synal, H.-A., 2005, Geomagnetic field intensity during the last 60,000 years based on $10 \mathrm{Be}$ and $36 \mathrm{Cl}$ from the Summit ice cores and 14C: Quaternary Science Reviews, v. 24, p. 1849-1860, doi:10.1016/j.quascirev.2005.01.012.

National Snow and Ice Data Center, 2017, NSIDC “About Glaciers”: All About Glaciers, https://nsidc.org/cryosphere/glaciers/information.html (accessed May 2017).

Nishiizumi, K., Winterer, E.L., Kohl, C.P., Klein, J., Middleton, R., Lal, D., and Arnold, J.R., 1989, Cosmic ray production rates of $10 \mathrm{Be}$ and $26 \mathrm{Al}$ in quartz from glacially polished rocks: Journal of Geophysical Research: Solid Earth, v. 94, p. 17907-17915, doi:10.1029/JB094iB12p17907.

N.O.A.A., 1976, U.S. Standard Atmosphere, 1976: US Gov., https://ntrs.nasa.gov/search.jsp?R=19770009539.

Onyeagocha, A.C., 1978, Twin Sisters dunite: Petrology and mineral chemistry: Geological Society of America Bulletin, v. 89, p. 1459, doi:10.1130/0016-7606(1978)89<1459:TSDPAM>2.0.CO;2.

Osborn, G., Menounos, B., Ryane, C., Riedel, J., Clague, J.J., Koch, J., Clark, D., Scott, K., and Davis, P.T., 2012, Latest Pleistocene and Holocene glacier fluctuations on Mount Baker, Washington: Quaternary Science Reviews, v. 49, p. 33-51, doi:10.1016/j.quascirev.2012.06.004.

Palmer, S., Walker, I., Heinrichs, M., and Scudder, G., 2002, Postglacial midge community change and Holocene palaeotemperaturereconstructions near treeline, southern British Columbia (Canada): Journal of Paleolimnology, v. 28, p. 469-490, doi:10.1023/A:1021644122727.

Pellatt, M.G., Smith, M.J., Mathewes, R.W., Walker, I.R., and Palmer, S.L., 2000, Holocene Treeline and Climate Change in the Subalpine Zone near Stoyoma Mountain, Cascade Mountains, Southwestern British Columbia, Canada: Arctic, Antarctic, and Alpine Research, v. 32, p. 73, doi:10.2307/1552412.

Porter, S.C., 1976, Pleistocene glaciation in the southern part of the North Cascade Range, Washington: Geological Society of America Bulletin, v. 87, p. 61, doi:10.1130/00167606(1976) 87<61:PGITSP>2.0.CO;2.

Porter, S.C., and Swanson, T.W., 1998, Radiocarbon Age Constraints on Rates of Advance and Retreat of the Puget Lobe of the Cordilleran Ice Sheet during the Last Glaciation: Quaternary Research, v. 50, p. 205-213, doi:10.1006/qres.1998.2004.

Ragan, D.M., 1963, Emplacement of the Twin Sisters dunite, Washington: American Journal of Science, v. 261, p. 549-565, doi:10.2475/ajs.261.6.549.

Ramsey, D., 2016, USGS Mt. Baker LiDAR:

Reheis, M.J., 1975, Source, Transportation and Deposition of Debris on Arapaho Glacier, Front Range, Colorado, U.S.A.: Journal of Glaciology, v. 14, p. 407-420, doi:10.3189/S0022143000021936.

Riedel, J.L., 2007, Late pleistocene glacial and environmental history of the Skagit valley, Washington and British Columbia [Thesis]: Dept. of Earth Sciences - Simon Fraser University, http://summit.sfu.ca/item/8099 (accessed January 2017).

Riedel, J.L., Clague, J.J., and Ward, B.C., 2010, Timing and extent of early marine oxygen isotope stage 2 alpine glaciation in Skagit Valley, Washington: Quaternary Research, v. 73, p. 313-323, doi:10.1016/j.yqres.2009.10.004.

Riihimaki, C.A., 2005, Sediment evacuation and glacial erosion rates at a small alpine glacier: Journal of Geophysical Research, v. 110, doi:10.1029/2004JF000189.

Sanders, J.W., Cuffey, K.M., MacGregor, K.R., and Collins, B.D., 2013, The sediment budget of an alpine cirque: Geological Society of America Bulletin, v. 125, p. 229-248, doi:10.1130/B30688.1.

Schildgen, T.F., Phillips, W.M., and Purves, R.S., 2005, Simulation of snow shielding corrections for cosmogenic nuclide surface exposure studies: Geomorphology, v. 64, p. 67-85, doi:10.1016/j.geomorph.2004.05.003. 
Smith, D.B., 1995, United States Geological Survey Certificate of Analysis, Dunite, DTS-1:, https://crustal.usgs.gov/geochemical_reference_standards/pdfs/dunite.pdf.

Stelling, P.L., and Tucker, D.S. (Eds.), 2007, Floods, faults, and fire: geological field trips in Washington State and southwest British Columbia: Boulder, Colo, Geological Society of America, Field guide / Geological Society of America 9, 255 p.

Stone, J.O., 2000, Air pressure and cosmogenic isotope production: Journal of Geophysical Research: Solid Earth, v. 105, p. 23753-23759, doi:10.1029/2000JB900181.

Tabor, R.W., Haugerud, R.A., Hildreth, W., and Brown, E.H., 2003, Geologic Map of the Mount Baker 30- by 60-Minute Quadrangle, Washington: United States Geological Survey Geologic Investigations Series I-2660 Geologic Map.

Thorson, R.M., 1980, Ice-Sheet Glaciation of the Puget lowland, Washington, during the Vashon Stade (late pleistocene): Quaternary Research, v. 13, p. 303-321, doi:10.1016/0033-5894(80)90059-9.

Tikoff, B., Larson, C.E., Newman, J., and Little, T., 2010, Field-based constraints on finite strain and rheology of the lithospheric mantle, Twin Sisters, Washington: Lithosphere, v. 2, p. 418-422, doi:10.1130/L97.1.

Tschudi, S., Ivy-Ochs, S., Schlüchter, C., Kubik, P., and Rainio, H., 2000, 10Be dating of Younger Dryas Salpausselkä I formation in Finland: Boreas, v. 29, p. 287-293, doi:10.1111/j.15023885.2000.tb01211.x.

Walker, I.R., and Pellatt, M.G., 2003, Climate Change in Coastal British Columbia - A Paleoenvironmental Perspective: Canadian Water Resources Journal / Revue canadienne des ressources hydriques, v. 28, p. 531-566, doi:10.4296/cwrj2804531.

Wershow, H.N., 2016, A Holocene Glaciolacustrine Record of the Lyman Glacier and Implications for Glacier Fluctuations in the North Cascades, Washington: Western Washington University, http://cedar.wwu.edu/wwuet/513 (accessed November 2016).

Whitlock, C., 1992, Vegetational and climatic history of the Pacific Northwest during the last 20,000 years: implications for understanding present-day biodiversity: Northwest Environmental Journal, v. 8 , p. 5-5.

Wigmosta, M.S., Nijssen, B., Storck, P., and Lettenmaier, D.P., 2002, The Distributed Hydrology Soil Vegetation Model, in Mathematical Models of Small Watershed Hydrology and Applications, Water Resources Publication, p. 7-42. 


\subsection{Tables}

Table 1: Measured ${ }^{3} \mathrm{He}$ and ${ }^{4} \mathrm{He}$ concentrations in all samples, with mantle ${ }^{3} \mathrm{He}{ }^{4} \mathrm{He}$, cosmogenic ${ }^{3} \mathrm{He}$, and model exposure age calculations. Uncertainty from snow shielding is excluded. Samples that were removed from analyses due to high background ${ }^{3}$ He uncertainties are shown in grey.

\begin{tabular}{|c|c|c|c|c|c|c|c|c|c|}
\hline \multirow{3}{*}{$\begin{array}{c}\text { Sample } \\
\text { LL1 }\end{array}$} & \multirow{3}{*}{$\begin{array}{c}\text { Elevation } \\
(\mathrm{m})\end{array}$} & \multirow{3}{*}{$\frac{{ }^{3} \mathrm{He}(\mathrm{pcc} / \mathrm{g})}{0.153}$} & \multirow{3}{*}{$\frac{{ }^{4} \mathrm{He}(\mathrm{ncc} / \mathrm{g})}{4.058}$} & \multirow{3}{*}{$\begin{array}{c}{ }^{3} \mathrm{He} /{ }^{4} \mathrm{He} \\
\left(\mathrm{R}_{\mathrm{A}}\right)\end{array}$} & \multicolumn{3}{|c|}{ Cosmogenic ${ }^{3} \mathrm{He}(\mathrm{Mat} / \mathrm{g})$, mantle $\mathrm{R}_{\mathrm{A}}=$} & \multirow{2}{*}{\multicolumn{2}{|c|}{$\begin{array}{c}\text { Model Exposure Age } \\
\text { (yrs), [1 } \sigma \text { error, excluding } \\
\text { snow shielding] }\end{array}$}} \\
\hline & & & & & \multirow{2}{*}{$\begin{array}{c}1.8 \\
3.832\end{array}$} & \multirow{2}{*}{2.3} & \multirow{2}{*}{$\begin{array}{c}2.8 \\
3.679\end{array}$} & & \\
\hline & & & & & & & & 13,800 & \pm 300 \\
\hline LL3 & 1058 & 0.115 & 4.721 & 17.56 & 2.777 & 2.689 & 2.600 & 11,900 & \pm 400 \\
\hline LL4 & 1051 & 0.205 & 10.65 & 13.88 & 4.800 & 4.599 & 4.399 & 18,700 & \pm 00 \\
\hline LL5 & 1038 & 0.229 & 13.51 & 12.18 & 5.234 & 4.980 & 4.726 & 21,500 & $\pm 1,000$ \\
\hline LL6 & 1055 & 0.086 & 3.223 & 19.00 & 2.086 & 2.025 & 1.964 & 7,800 & \pm 200 \\
\hline LL8 & 1070 & 0.153 & 21.90 & 5.028 & 2.629 & 2.217 & 1.806 & 8,000 & $\pm 1,500$ \\
\hline T1S2 & 1540 & 0.055 & 15.47 & 2.531 & 0.425 & 0.134 & -0.157 & 400 & \pm 800 \\
\hline T1S3 & 1478 & 0.084 & 11.89 & 5.026 & 1.443 & 1.219 & 0.996 & 3,800 & \pm 700 \\
\hline T1S6 & 1421 & 0.131 & 17.40 & 5.371 & 2.338 & 2.010 & 1.683 & 6,400 & $\pm 1,000$ \\
\hline T1S7 & 1401 & 0.058 & 2.205 & 18.63 & 1.396 & 1.355 & 1.313 & 4,400 & \pm 150 \\
\hline $\mathrm{T} 1 \mathrm{~S} 8$ & 1381 & 0.130 & 2.220 & 41.72 & 3.334 & 3.292 & 3.251 & 10,500 & \pm 100 \\
\hline $\mathrm{T} 2 \mathrm{~S} 1$ & 1339 & 0.117 & 22.16 & 3.770 & 1.643 & 1.226 & 0.809 & 4,300 & $\pm 1,500$ \\
\hline $\mathrm{T} 2 \mathrm{~S} 7$ & 1546 & 0.126 & 26.37 & 3.435 & 1.598 & 1.102 & 0.606 & 3,200 & $\pm 1,500$ \\
\hline T3S1 & 1658 & 0.059 & 19.60 & 2.156 & 0.262 & -0.106 & -0.475 & 0 & \pm 900 \\
\hline T3S3 & 1616 & 0.056 & 10.91 & 3.685 & 0.774 & 0.568 & 0.363 & 1,600 & \pm 600 \\
\hline T3S4 & 1566 & 0.063 & 8.068 & 5.614 & 1.158 & 1.006 & 0.854 & 3,000 & \pm 500 \\
\hline T3S5 & 1549 & 0.129 & 17.85 & 5.191 & 2.253 & 1.917 & 1.581 & 5,500 & $\pm 1,000$ \\
\hline T3S6 & 1506 & 0.117 & 13.24 & 6.385 & 2.261 & 2.012 & 1.763 & 6,000 & \pm 750 \\
\hline T3S7 & 1466 & 0.187 & 21.34 & 6.255 & 3.576 & 3.175 & 2.773 & 9,600 & $\pm 1,200$ \\
\hline T3S8 & 1419 & 0.149 & 11.65 & 9.209 & 3.218 & 2.999 & 2.780 & 9,400 & \pm 700 \\
\hline LL2 & 1067 & 0.258 & 60.11 & 3.070 & 2.873 & 1.742 & 0.611 & 6,500 & $\pm 4,200$ \\
\hline LL7 & 1031 & 0.241 & 91.11 & 1.902 & 0.302 & -1.412 & -3.126 & 5,300 & $\pm 6,400$ \\
\hline $\mathrm{T} 1 \mathrm{~S} 1$ & 1546 & 0.680 & 288.3 & 1.686 & -1.239 & -6.662 & -12.085 & $-18,900$ & $\pm 14,500$ \\
\hline $\mathrm{T} 1 \mathrm{~S} 4$ & 1456 & 0.906 & 323.5 & 2.001 & 2.443 & -3.643 & -9.730 & $-8,600$ & $\pm 16,800$ \\
\hline $\mathrm{T} 1 \mathrm{~S} 5$ & 1439 & 0.136 & 45.37 & 2.162 & 0.591 & -0.263 & -1.116 & -800 & $\pm 2,600$ \\
\hline T1S9a & 1614 & 0.131 & 52.89 & 1.784 & -0.057 & -1.052 & -2.047 & $-2,800$ & $\pm 2,600$ \\
\hline T1S9b & 1615 & 0.183 & 68.69 & 1.917 & 0.268 & -1.025 & -2.317 & $-2,700$ & $\pm 3,400$ \\
\hline $\mathrm{T} 2 \mathrm{~S} 2$ & 1347 & 0.163 & 71.39 & 1.639 & -0.465 & -1.808 & -3.151 & $-6,000$ & $\pm 4,600$ \\
\hline $\mathrm{T} 2 \mathrm{~S} 3$ & 1376 & 1.552 & 518.2 & 2.139 & 6.619 & -3.131 & -12.880 & $-6,500$ & $\pm 32,000$ \\
\hline $\mathrm{T} 2 \mathrm{~S} 4$ & 1422 & 0.824 & 216.9 & 2.712 & 7.445 & 3.364 & -0.716 & 12,600 & $\pm 14,700$ \\
\hline T2S5 & 1447 & 0.172 & 32.88 & 3.770 & 2.404 & 1.786 & 1.167 & 5,800 & $\pm 2,000$ \\
\hline T2S6 & 1496 & 0.252 & 95.91 & 1.889 & 0.273 & -1.532 & -3.336 & $-4,300$ & $\pm 5,000$ \\
\hline $\mathrm{T} 2 \mathrm{~S} 8$ & 1570 & 2.160 & 1037 & 1.487 & -12.242 & -31.769 & -51.296 & $-86,000$ & $\pm 45,700$ \\
\hline T3S2 & 1682 & 0.475 & 221.0 & 1.547 & -2.194 & -6.353 & -10.511 & $-14,700$ & $\pm 8,500$ \\
\hline
\end{tabular}


Table 2: Snow shielding correction estimates from DHSVM and SNOTEL sites

\begin{tabular}{|ll|ll|}
\hline Method/Location & Snow Correction & Method/Location & Snow Correction \\
\hline DHSVM Lowland: Low & 0.98 & DHSVM Forefield: Low & 0.79 \\
DHSVM Lowland: Med & 0.94 & DHSVM Forefield: Med & 0.74 \\
DHSVM Lowland: High & 0.91 & DHSVM Forefield: High & 0.67 \\
\hline Elbow Lake (ele. 927) & 0.90 & Wells Creek (ele. 1533) & $0.91-0.92$ \\
Skookum Creek (ele. 1009) & 0.93 & Surprise Lakes (ele. 1308) & $0.86-0.88$ \\
Alpine Meadows (ele. 1067) & 0.85 & Bumping Ridge (ele. 1405) & $0.92-0.93$ \\
Stevens Pass (ele. 1204) & 0.89 & MF Nooksack (ele. 1515) & $0.81-0.83$ \\
\hline Lowland Range & $\mathbf{0 . 9 8 - 0 . 8 5}$ & Forefield Range & $\mathbf{0 . 9 3 - \mathbf { 0 . 6 7 }}$ \\
Lowland Average & $\mathbf{0 . 9 1}$ & Forefield Average & $\mathbf{0 . 8 0}$ \\
\hline
\end{tabular}


Table 3: Sample locations, observations, model exposure ages, erosion depths, and erosion rates with uncertainties related to mantle ${ }^{3} \mathrm{He}{ }^{4} \mathrm{He}$ ratio, snow shielding, and period of glacier cover included. Samples filled with "N/A" did not contain sufficient cosmogenic ${ }^{3}$ He to calculate an erosion depth and rate. Samples that were removed from analyses due to high mantle ${ }^{4} \mathrm{He}$ are shown in grey.

\begin{tabular}{|c|c|c|c|c|c|c|c|c|c|c|c|c|}
\hline \multirow{2}{*}{$\frac{\text { Sample }}{\text { LL1 }}$} & \multirow{2}{*}{$\frac{\text { Lat. }}{48.7228}$} & \multirow{2}{*}{$\begin{array}{r}\text { Long. } \\
-121.975\end{array}$} & \multirow{2}{*}{$\begin{array}{c}\begin{array}{c}\text { Elevation } \\
(\mathrm{m})\end{array} \\
1059\end{array}$} & \multirow{2}{*}{$\begin{array}{c}\text { Thickness } \\
\text { (cm) }\end{array}$} & \multirow{2}{*}{$\begin{array}{l}\text { Oxidation } \\
\text { heavy }\end{array}$} & \multirow{2}{*}{$\begin{array}{c}\begin{array}{c}\text { Striated? } \\
\mathrm{y} / \mathrm{n}\end{array} \\
\mathrm{n}\end{array}$} & \multicolumn{2}{|c|}{$\begin{array}{l}\text { Model Exposure Age } \\
\text { (yrs, } 1 \sigma \text { error) }\end{array}$} & \multicolumn{2}{|c|}{$\begin{array}{l}\text { Erosion Depth } \\
\text { (cm, } 1 \sigma \text { error) }\end{array}$} & \multicolumn{2}{|c|}{$\begin{array}{c}\text { Erosion Rate } \\
(\mathrm{mm} / \mathrm{yr}, 1 \sigma \text { error })\end{array}$} \\
\hline & & & & & & & 13,800 & $\begin{array}{l}+1,300 \\
-1,250\end{array}$ & & & & \\
\hline LL3 & 48.7240 & -121.975 & 1058 & 1.4 & heavy & $\mathrm{n}$ & 11,900 & $\begin{array}{l}+1,300 \\
-1,200\end{array}$ & & & & \\
\hline LL4 & 48.7246 & -121.976 & 1051 & 2 & heavy & $\mathrm{n}$ & 18,700 & $\begin{array}{l}+2,200 \\
-2,100\end{array}$ & & & & \\
\hline LL5 & 48.7252 & -121.976 & 1038 & 2.2 & heavy & $\mathrm{n}$ & 21,500 & $\begin{array}{l}+2,700 \\
-2,600\end{array}$ & & & & \\
\hline LL6 & 48.7229 & -121.977 & 1055 & 2 & heavy & $\mathrm{n}$ & 7,800 & $\begin{array}{l}+800 \\
-800\end{array}$ & & & & \\
\hline LL8 & 48.7225 & -121.977 & 1070 & 2 & med & $\mathrm{n}$ & 8,000 & $\begin{array}{l}+1,800 \\
-1.800\end{array}$ & & & & \\
\hline T1S2 & 48.7122 & -121.973 & 1540 & 5 & med & $\mathrm{n}$ & 400 & $\begin{array}{l}-1.800 \\
+1,100 \\
-800\end{array}$ & 146 & $\begin{array}{l}+\mathrm{N} / \mathrm{A} \\
-62.4\end{array}$ & 0.695 & ${ }_{-\mathrm{N} / \mathrm{A}}^{+\mathrm{N} / \mathrm{A}}$ \\
\hline T1S3 & 48.7135 & -121.973 & 1478 & 5.5 & med & $\mathrm{y}$ & 3,800 & $\begin{array}{l}-800 \\
+1,600 \\
-1,200\end{array}$ & 46.0 & $\begin{array}{l}-0.4 \\
+17.7 \\
-17.5\end{array}$ & 0.511 & $\begin{array}{l}-N / \mathrm{A} \\
+0.76 \\
-0.29\end{array}$ \\
\hline T1S6 & 48.7149 & -121.972 & 1421 & 3 & light & $\mathrm{n}$ & 6,400 & $\begin{array}{l}+2,500 \\
-1,800\end{array}$ & 22.3 & $\begin{array}{l}+16.6 \\
-16.7\end{array}$ & 0.248 & $\begin{array}{l}+0.53 \\
-0.21\end{array}$ \\
\hline T1S7 & 48.7153 & -121.972 & 1401 & 4 & med & $\mathrm{n}$ & 4,400 & $\begin{array}{l}+1,100 \\
+800\end{array}$ & 38.6 & $\begin{array}{l}+19.94 \\
-11.2\end{array}$ & 0.429 & $\begin{array}{l}+0.54 \\
-0.21\end{array}$ \\
\hline T1S8 & 48.7158 & -121.972 & 1381 & 4 & med & $\mathrm{y}$ & 10,500 & $\begin{array}{l}-800 \\
+2,200 \\
-1,600\end{array}$ & 1.18 & $\begin{array}{l}-11.2 \\
+9.05 \\
-10.3\end{array}$ & 0.024 & $\begin{array}{l}-0.21 \\
+0.99 \\
-0.13\end{array}$ \\
\hline $\mathrm{T} 2 \mathrm{~S} 1$ & 48.7159 & -121.975 & 1339 & 3.5 & light & $\mathrm{y}$ & 4,300 & $\begin{array}{l}-1,000 \\
+2,600 \\
-1,900\end{array}$ & 40.2 & $\begin{array}{l}-10.5 \\
+27.4 \\
-23.1\end{array}$ & 0.447 & $\begin{array}{l}-0.13 \\
+0.91 \\
-0.32\end{array}$ \\
\hline T2S7 & 48.7124 & -121.976 & 1546 & 2.5 & light & $\mathrm{y}$ & 3,200 & $\begin{array}{l}-1,900 \\
+2,400 \\
-1,700\end{array}$ & 47.4 & $\begin{array}{l}-2.1 \\
+35.9 \\
-26.9\end{array}$ & 0.226 & $\begin{array}{l}-0.52 \\
-0.26 \\
-0.14\end{array}$ \\
\hline T3S1 & 48.7128 & -121.982 & 1658 & 3.5 & light & $\mathrm{y}$ & 0 & $\begin{array}{l}-1,000 \\
+900 \\
-1,000\end{array}$ & N/A & $\begin{array}{l}-26.9 \\
+\mathrm{N} / \mathrm{A} \\
-\mathrm{N} / \mathrm{A}\end{array}$ & N/A & $\begin{array}{l}-0.14 \\
+\mathrm{N} / \mathrm{A} \\
-\mathrm{N} / \mathrm{A}\end{array}$ \\
\hline T3S3 & 48.7126 & -121.981 & 1616 & 1 & med & $\mathrm{y}$ & 1,600 & $\begin{array}{l}-1,000 \\
+1,000 \\
-700\end{array}$ & 80.1 & $\begin{array}{l}-1 \mathrm{~N} / \mathrm{A} \\
+29.1 \\
-24.0\end{array}$ & 0.385 & $\begin{array}{l}-1 / \mathrm{A} \\
+0.26 \\
-0.16\end{array}$ \\
\hline T3S4 & 48.7131 & -121.980 & 1566 & 3 & light & $\mathrm{y}$ & 3,000 & $\begin{array}{l}+1,100 \\
-800\end{array}$ & 51.0 & $\begin{array}{l}-24.0 \\
+16.2 \\
-16.4\end{array}$ & 0.243 & $\begin{array}{l}-0.10 \\
+0.15 \\
-0.11\end{array}$ \\
\hline T3S5 & 48.7137 & -121.980 & 1549 & 1.5 & light & $\mathrm{y}$ & 5,500 & $\begin{array}{l}-800 \\
+2,300 \\
-1,600\end{array}$ & 23.2 & $\begin{array}{l}-10.4 \\
+17.5 \\
-17.4\end{array}$ & 0.111 & $\begin{array}{l}-0.11 \\
+0.13 \\
-0.087\end{array}$ \\
\hline T3S6 & 48.7144 & -121.979 & 1506 & 3 & light & $\mathrm{y}$ & 6,000 & $\begin{array}{l}-1,000 \\
+2,100 \\
-1,500\end{array}$ & 20.9 & $\begin{array}{l}-1.4 \\
+14.7 \\
-15.3\end{array}$ & 0.123 & $\begin{array}{l}-0.087 \\
+0.15 \\
-0.096\end{array}$ \\
\hline T3S7 & 48.7149 & -121.979 & 1466 & 5 & light & $\mathrm{y}$ & 9,600 & $\begin{array}{l}-1,500 \\
+3,400 \\
-2,400\end{array}$ & 0.151 & $\begin{array}{l}-15.3 \\
+14.8 \\
-15.3\end{array}$ & 0.001 & $\begin{array}{l}-0.096 \\
+0.11 \\
-0.073\end{array}$ \\
\hline T3S8 & 48.7157 & -121.978 & 1419 & 1.5 & light & $\mathrm{y}$ & 9,500 & $\begin{array}{l}-2,400 \\
+2,700 \\
-1,900\end{array}$ & 4.56 & $\begin{array}{l}-15.3 \\
+12.0 \\
-13.0\end{array}$ & 0.051 & $\begin{array}{l}-0.0 / 3 \\
+0.28 \\
-0.12\end{array}$ \\
\hline LL2 & 48.7228 & -121.975 & 1067 & 3.8 & heavy & $\mathrm{n}$ & 6,500 & $\begin{array}{l}+4,600 \\
-4,300\end{array}$ & & & & \\
\hline LL7 & 48.7228 & -121.974 & 1031 & 5 & heavy & $\mathrm{n}$ & $-5,300$ & $\begin{array}{l}+6,400 \\
-5,900\end{array}$ & & & & \\
\hline T1S1 & 48.7121 & -121.973 & 1546 & 4.5 & med & $\mathrm{y}$ & $-20,800$ & $\begin{array}{l}+16,700 \\
-13,900\end{array}$ & N/A & ${ }_{-N / A}^{+N / A}$ & $\mathrm{~N} / \mathrm{A}$ & ${ }_{-N / A}^{+N / A}$ \\
\hline T1S4 & 48.7141 & -121.972 & 1456 & 7 & med & $\mathrm{y}$ & $-10,700$ & $\begin{array}{l}+19,600 \\
-14,100\end{array}$ & $\mathrm{~N} / \mathrm{A}$ & $\begin{array}{l}+\mathrm{N} / \mathrm{A} \\
-\mathrm{N} / \mathrm{A}\end{array}$ & $\mathrm{N} / \mathrm{A}$ & ${ }_{-N / A}^{+N / A}$ \\
\hline T1S5 & 48.7145 & -121.972 & 1439 & 4.5 & light & $\mathrm{n}$ & -800 & $\begin{array}{l}+3,000 \\
-2,100\end{array}$ & N/A & ${ }_{-N / A}^{+N / A}$ & $\mathrm{~N} / \mathrm{A}$ & ${ }_{-N / A}^{+N / A}$ \\
\hline T1S9a & 48.7110 & -121.974 & 1614 & $<1$ & light & $\mathrm{y}$ & $-2,800$ & $\begin{array}{l}+2,600 \\
-1,900\end{array}$ & N/A & $\begin{array}{l}+\mathrm{N} / \mathrm{A} \\
-\mathrm{N} / \mathrm{A}\end{array}$ & $\mathrm{N} / \mathrm{A}$ & ${ }_{-N / A}^{+N / A}$ \\
\hline T1S9b & 48.7110 & -121.974 & 1615 & 3 & none & $\mathrm{n}$ & $-2,700$ & $\begin{array}{l}+3,600 \\
-2,600\end{array}$ & $\mathrm{~N} / \mathrm{A}$ & ${ }_{-N / A}^{+N / A}$ & $\mathrm{~N} / \mathrm{A}$ & $\begin{array}{l}+\mathrm{N} / \mathrm{A} \\
-\mathrm{N} / \mathrm{A}\end{array}$ \\
\hline $\mathrm{T} 2 \mathrm{~S} 2$ & 48.7156 & -121.975 & 1347 & 4.5 & light & $\mathrm{y}$ & $-6,100$ & $\begin{array}{l}+4,300 \\
-3,100\end{array}$ & $\mathrm{~N} / \mathrm{A}$ & ${ }_{-N / A}^{+N / A}$ & $\mathrm{~N} / \mathrm{A}$ & ${ }_{-\mathrm{N} / \mathrm{A}}^{+\mathrm{N} / \mathrm{A}}$ \\
\hline $\mathrm{T} 2 \mathrm{~S} 3$ & 48.7150 & -121.975 & 1376 & 4 & med & $\mathrm{n}$ & $-10,500$ & $\begin{array}{l}+37,900 \\
-27,300\end{array}$ & N/A & ${ }_{-N / A}^{+N / A}$ & $\mathrm{~N} / \mathrm{A}$ & ${ }_{-\mathrm{N} / \mathrm{A}}^{+\mathrm{N} / \mathrm{A}}$ \\
\hline T2S4 & 48.7146 & -121.975 & 1422 & 3.5 & med & $\mathrm{y}$ & 10,800 & $\begin{array}{l}+18,100 \\
-13,000\end{array}$ & 2.23 & $\begin{array}{l}+\mathrm{N} / \mathrm{A} \\
-50.4\end{array}$ & $\mathrm{~N} / \mathrm{A}$ & $\begin{array}{l}+\mathrm{N} / \mathrm{A} \\
-\mathrm{N} / \mathrm{A}\end{array}$ \\
\hline T2S5 & 48.7143 & -121.975 & 1447 & 3.5 & light & $\mathrm{y}$ & 5,800 & $\begin{array}{l}+3,600 \\
-2,600\end{array}$ & 33.3 & $\begin{array}{l}+30.5 \\
-25.5\end{array}$ & $\mathrm{~N} / \mathrm{A}$ & ${ }_{-\mathrm{N} / \mathrm{A}}^{+\mathrm{N} / \mathrm{A}}$ \\
\hline T2S6 & 48.7134 & -121.975 & 1496 & 3 & med & $y$ & $-4,300$ & $\begin{array}{l}+5,300 \\
-3,900\end{array}$ & N/A & $\begin{array}{l}+\mathrm{N} / \mathrm{A} \\
-\mathrm{N} / \mathrm{A}\end{array}$ & $\mathrm{N} / \mathrm{A}$ & ${ }_{-N / A}^{+N / A}$ \\
\hline T2S8 & 48.7118 & -121.976 & 1570 & 9 & light & $\mathrm{y}$ & $-91,900$ & $\begin{array}{l}+50,600 \\
-36,400\end{array}$ & $\mathrm{~N} / \mathrm{A}$ & ${ }_{-N / A}^{+N / A}$ & $\mathrm{~N} / \mathrm{A}$ & ${ }_{-\mathrm{N} / \mathrm{A}}^{+\mathrm{N} / \mathrm{A}}$ \\
\hline T3S2 & 48.7119 & -121.983 & 1682 & 2 & light & $\mathrm{y}$ & $-15,800$ & $\begin{array}{l}+9,500 \\
-6,800\end{array}$ & $\mathrm{~N} / \mathrm{A}$ & ${ }_{-N / A}^{+N / A}$ & $\mathrm{~N} / \mathrm{A}$ & ${ }_{-\mathrm{N} / \mathrm{A}}^{+\mathrm{N} / \mathrm{A}}$ \\
\hline
\end{tabular}




\subsection{Figures}
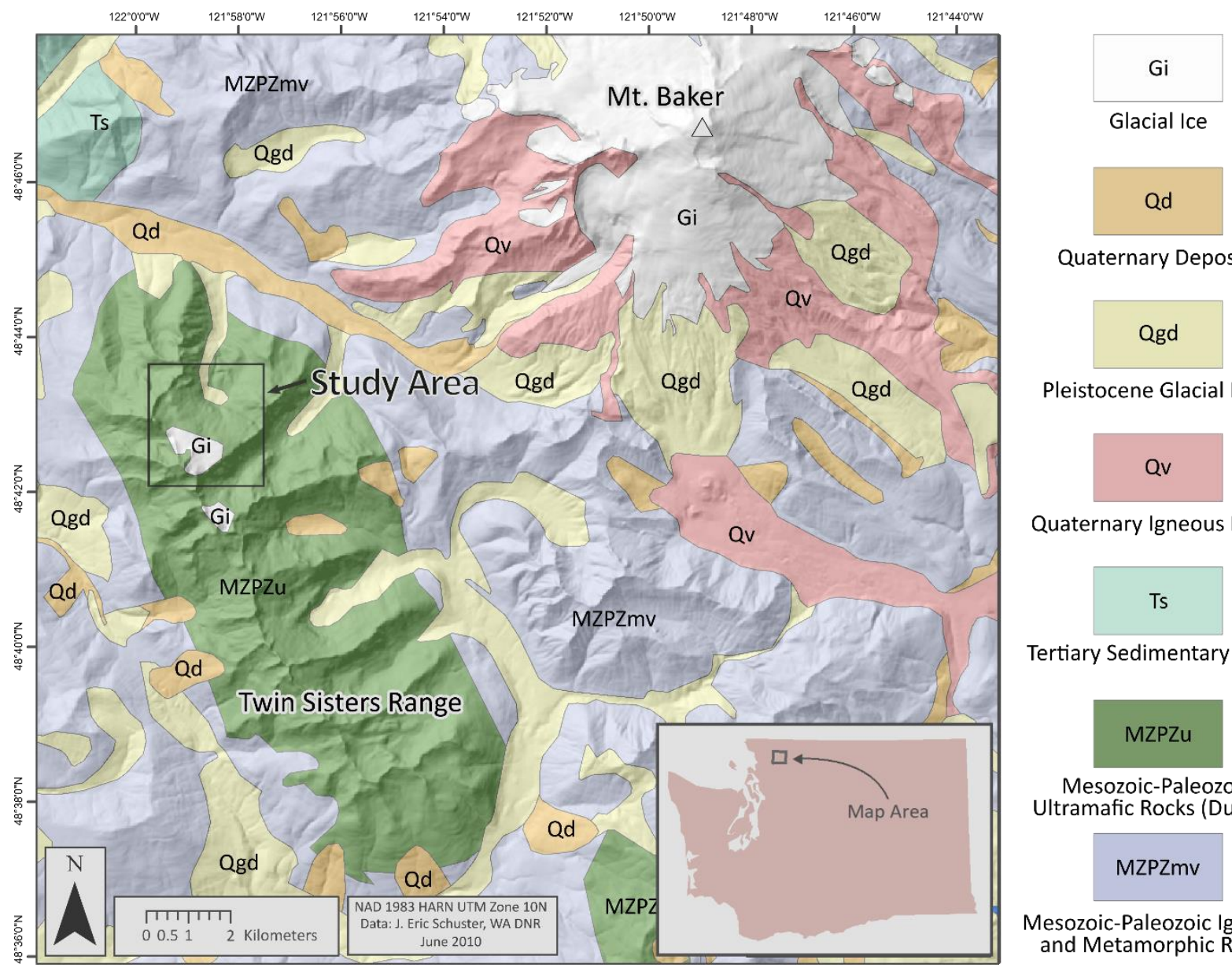

Quaternary Deposits

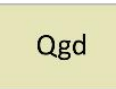

Pleistocene Glacial Drift

Qv

Quaternary Igneous Rocks

\section{Ts}

Tertiary Sedimentary Rocks

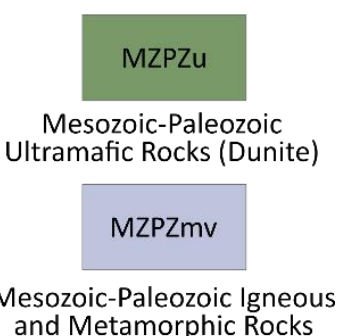

Figure 1: Simplified geologic map of the Twin Sisters Range and surrounding area. Inset map shows location within the state of Washington. 


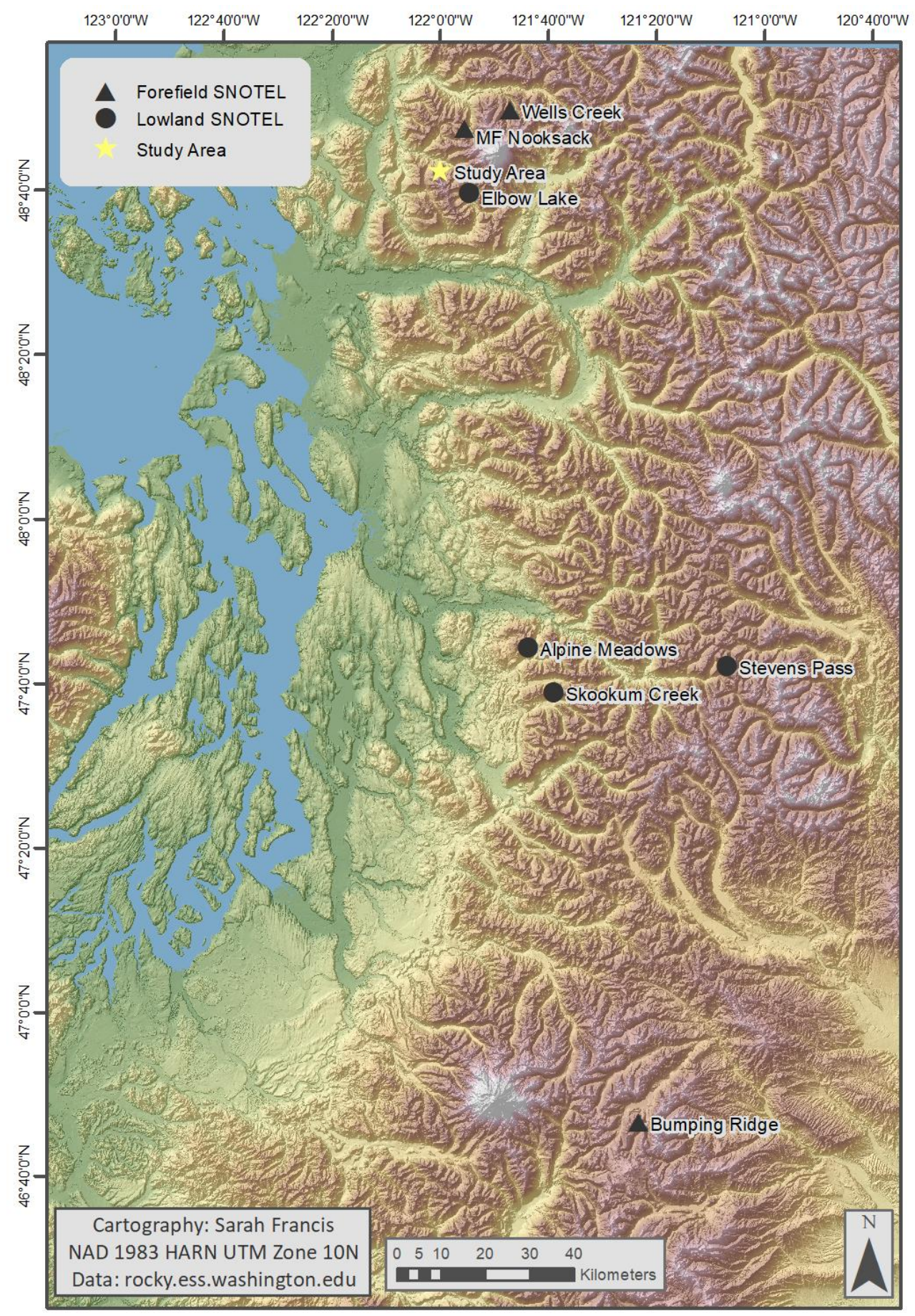

Figure 2: SNOTEL site locations used for snow shielding calculations 


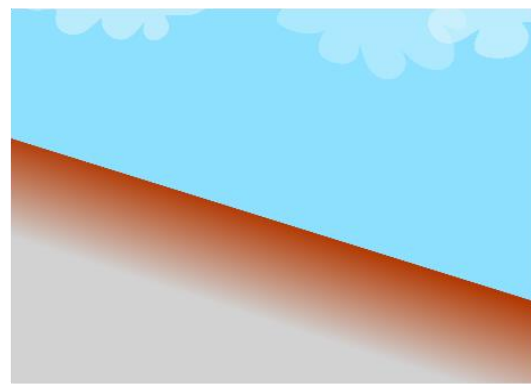

Early Holocene: Helium 3 (brown) accumulates in bedrock as a result of cosmic ray exposure.

Accumulation decreases exponentially with depth Non-glacial erosion is assumed to be zero.

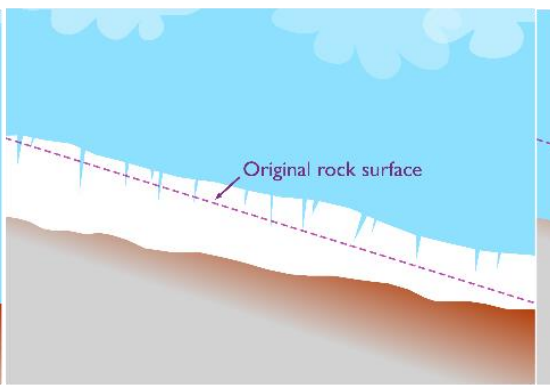

Late Holocene: Sisters glacier advances during Neoglacial period. Subglacial erosion removes surficial rock that had accumulated cosmogenic helium 3 .

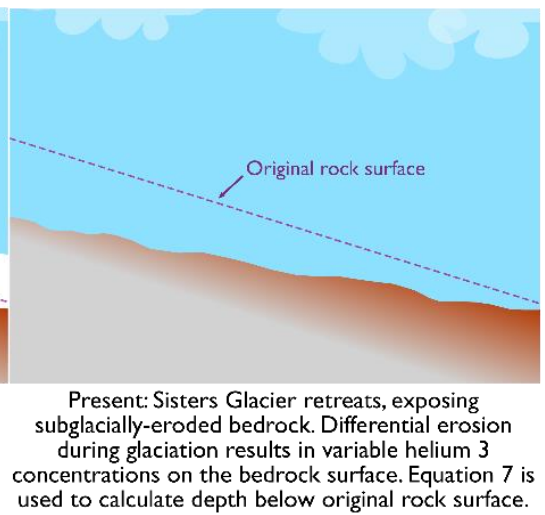

Figure 3: Simplified cartoon schematic showing how subglacial erosion removes bedrock with accumulated ${ }^{3} \mathrm{He}$ in the Twin Sisters.

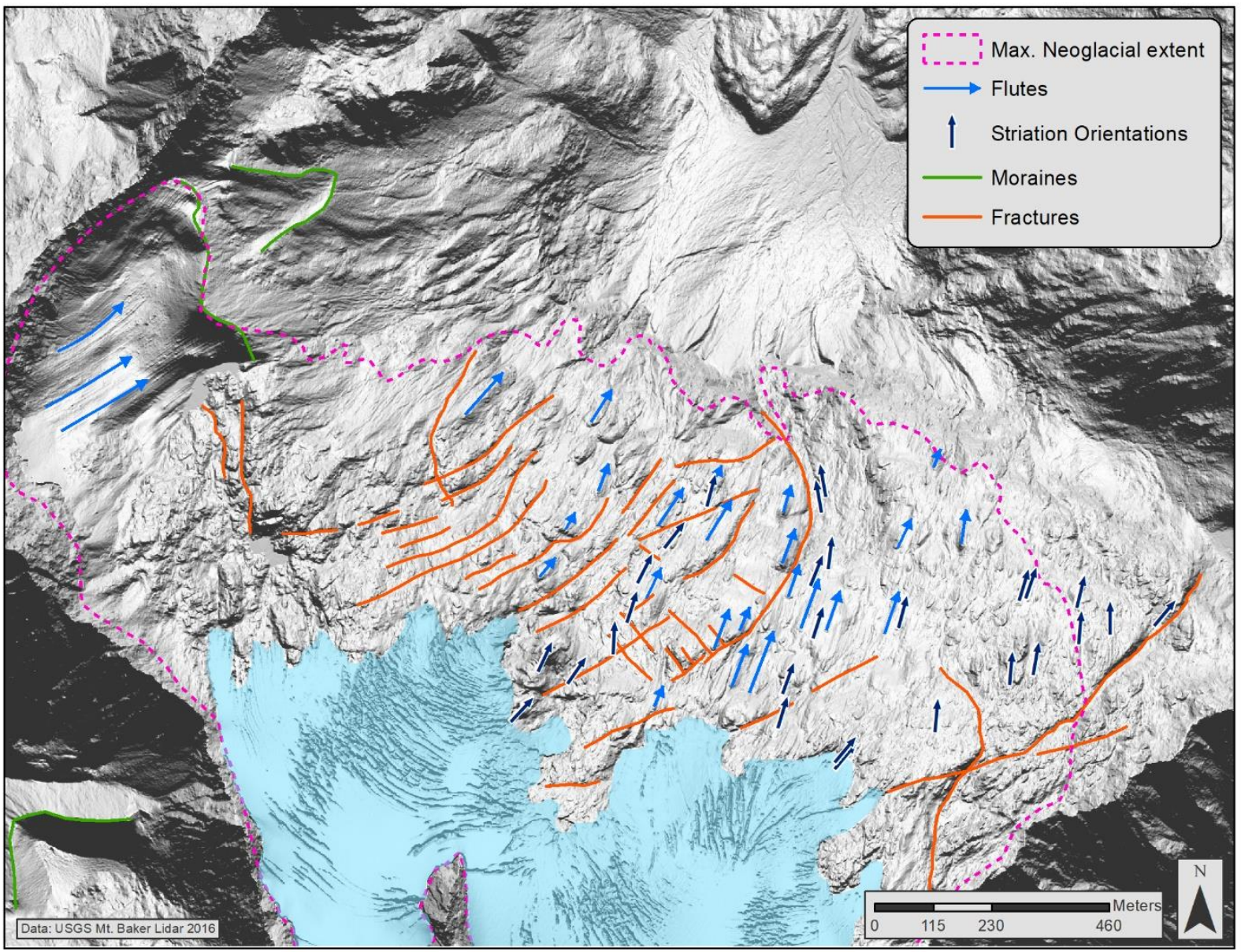

Figure 4: Lidar hillshade showing prominent glacial flow indicators, moraines, and bedrock fractures. Blue indicates extent of glacial ice as of 2016. 


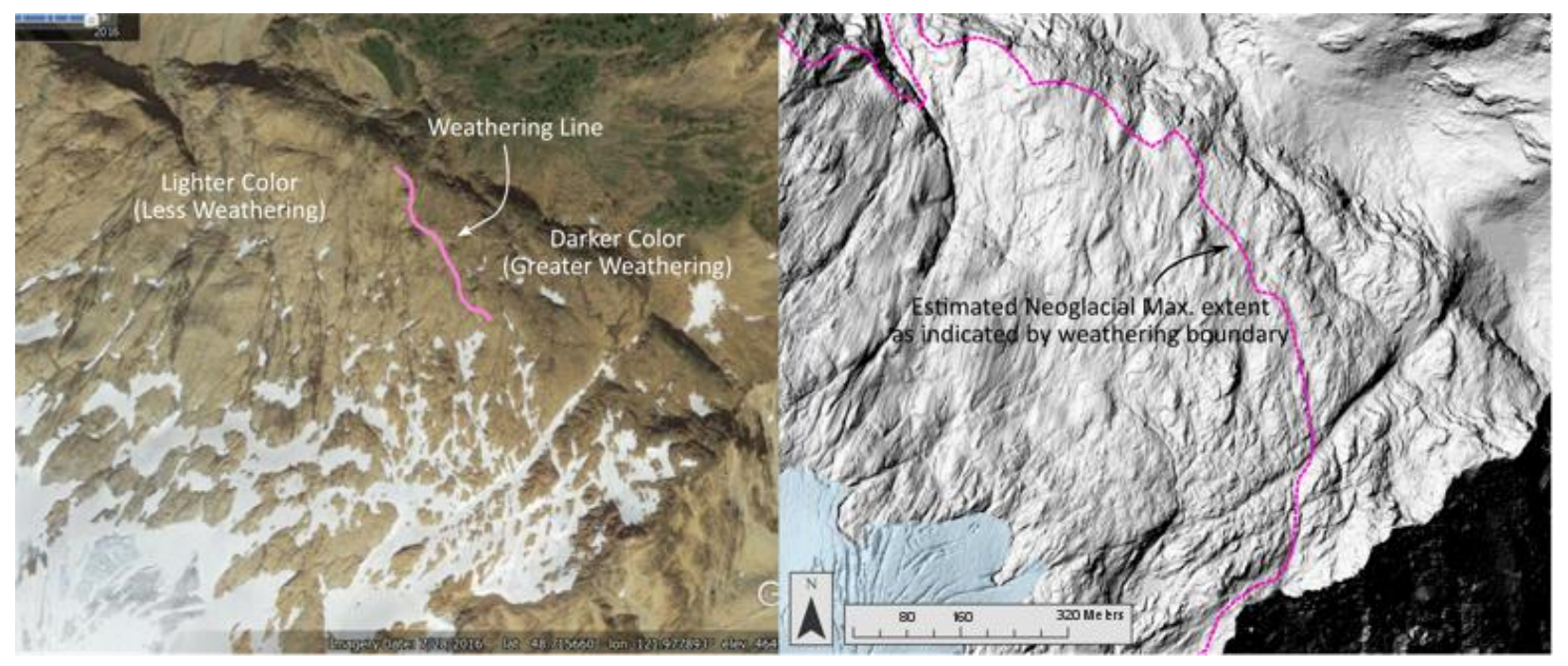

Figure 5: Lidar hillshade and Google Earth images indicating Neoglacial ice limit as inferred from scattered till deposits and distinct change in bedrock weathering. 


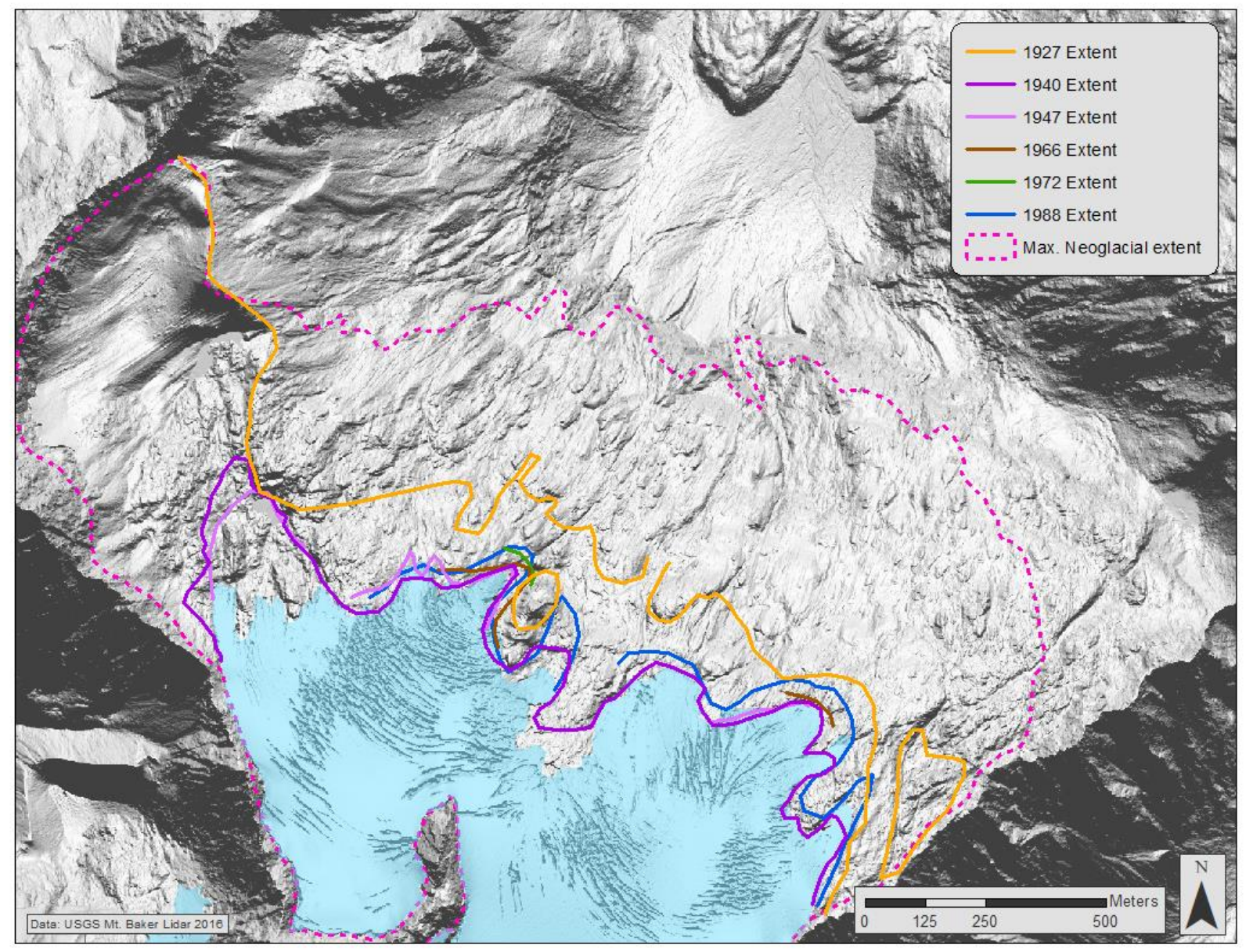

Figure 6: Results of analyses of historical aerial imagery showing $20^{\text {th }}$ Century extents of the Sisters Glacier 


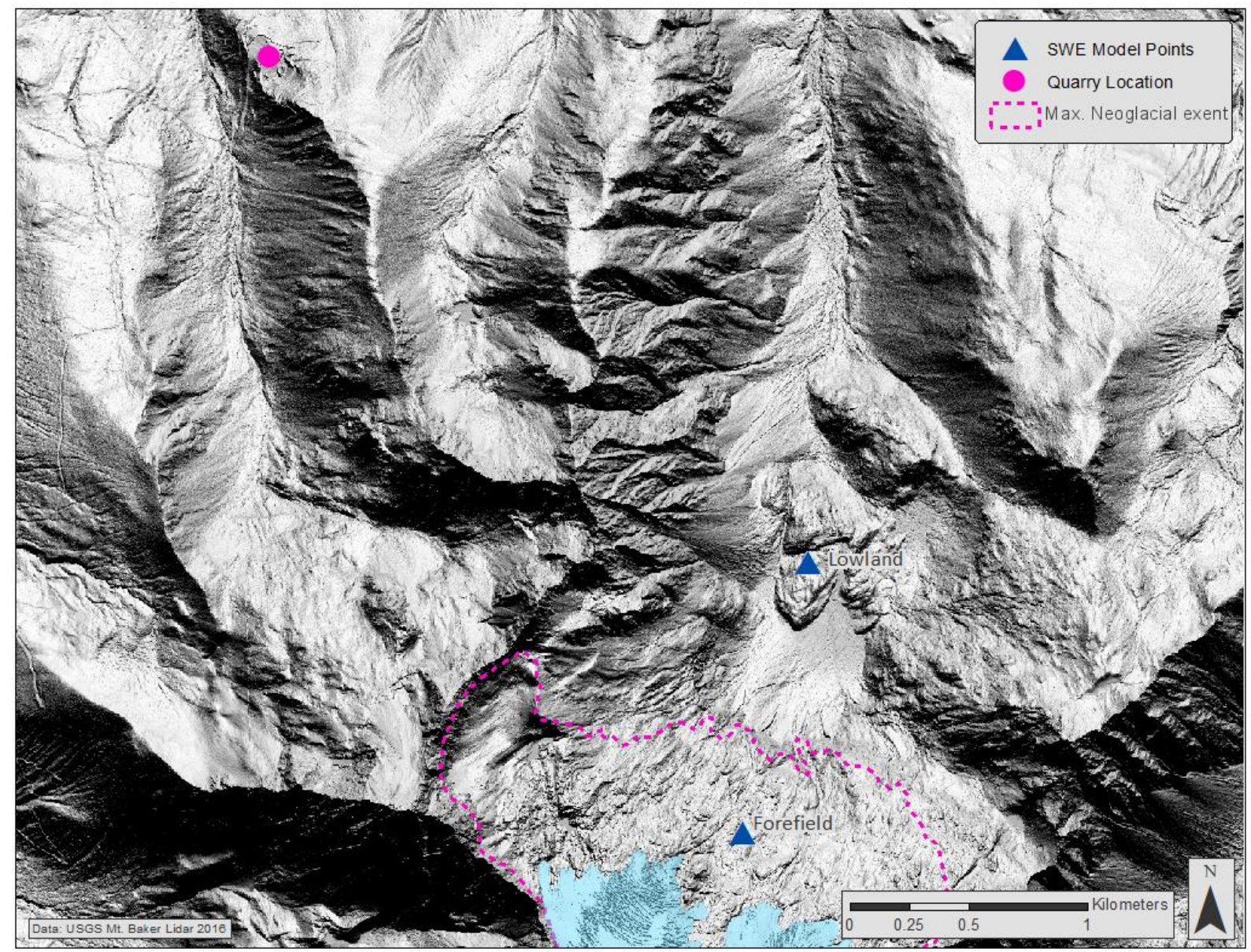

Figure 7: Lidar hillshade indicating Sven Larsen bedrock quarry location and sites of forefield and lowland DHSVM snow-depth model runs. 


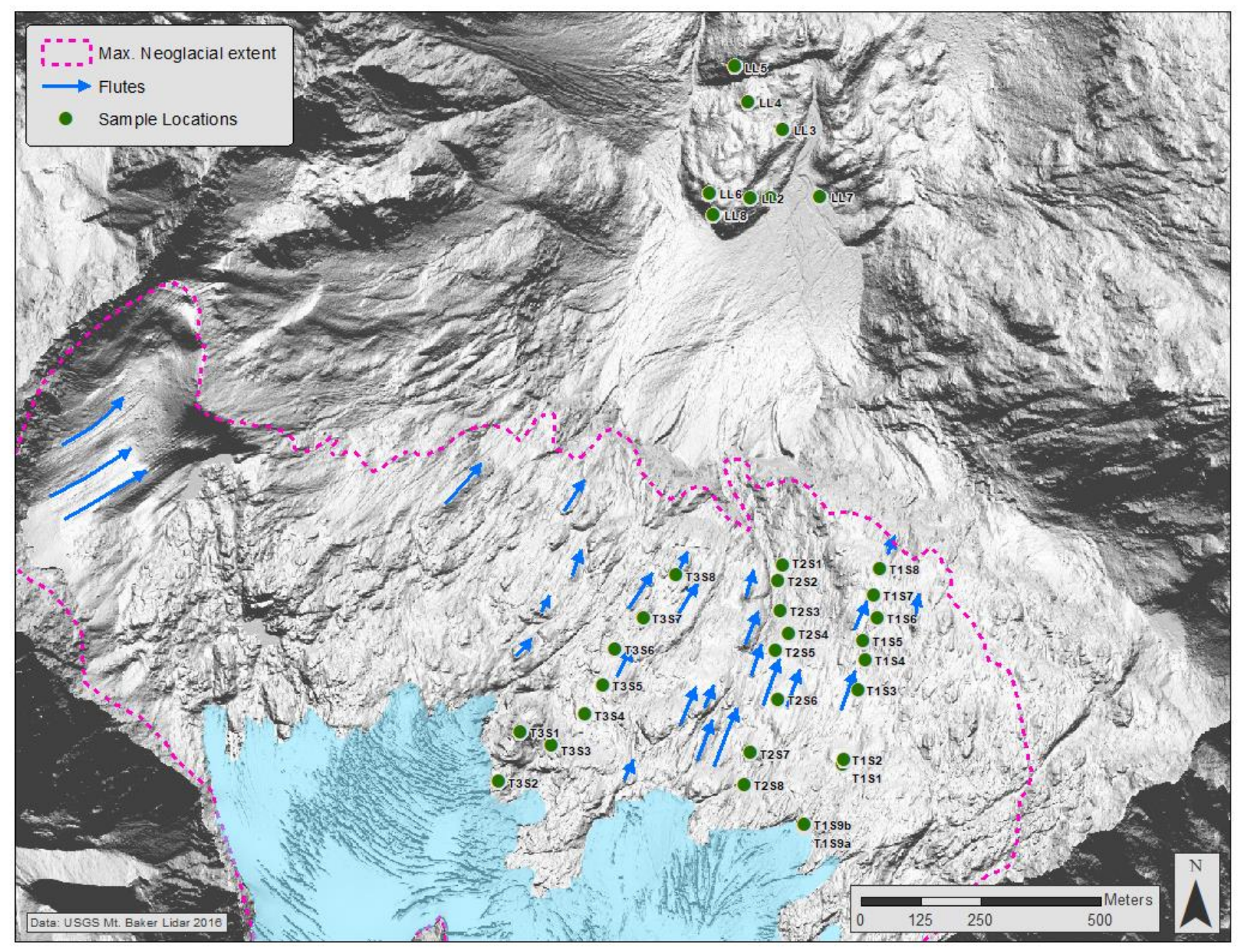

Figure 8: Sample locations along longitudinal transects roughly parallel to ice-flow indicators. 


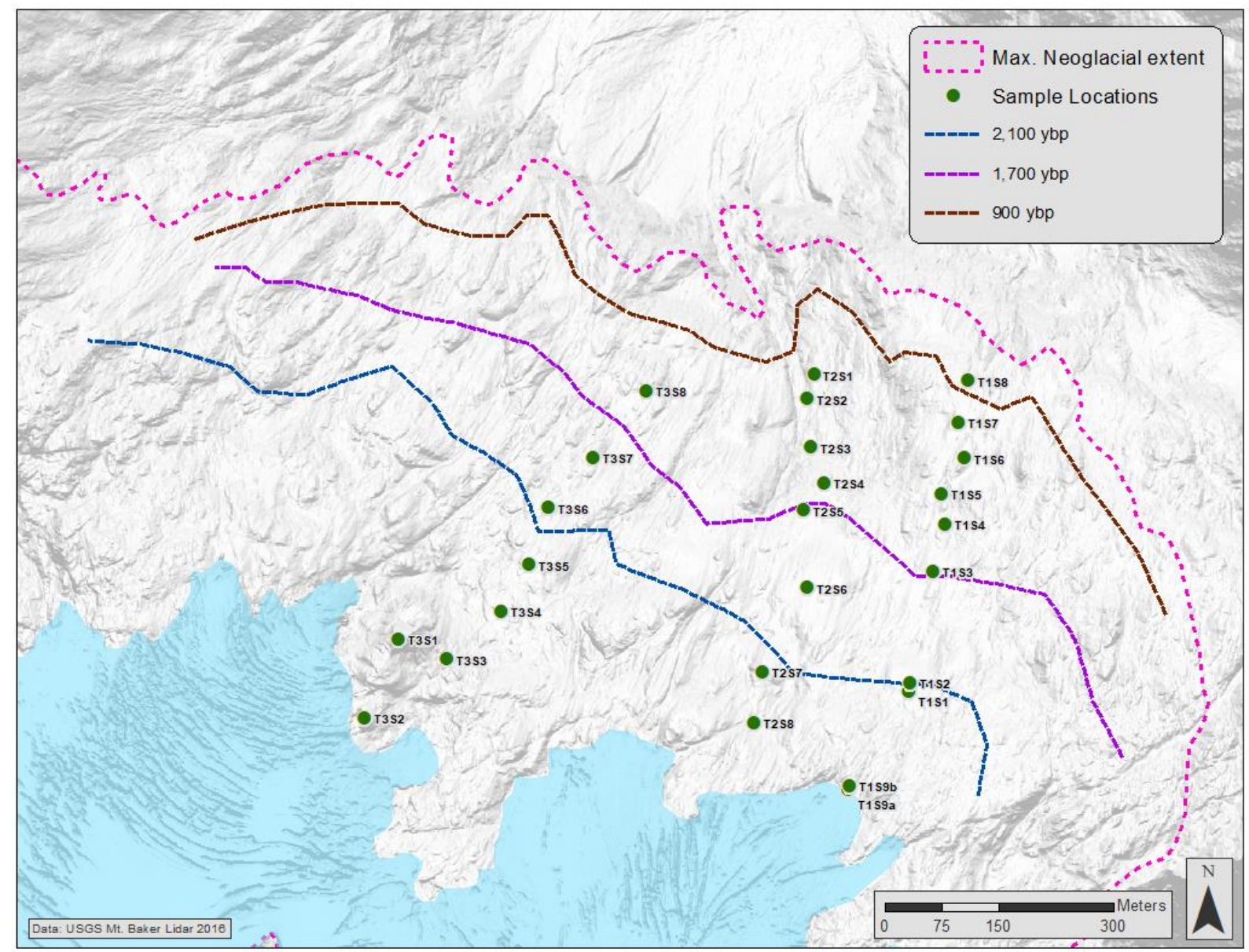

Figure 9: Estimated locations of Neoglacial terminal positions of Sisters Glacier relative to sample locations, based on correlation to normalized ice extents from the Mt. Baker glacier record (Osborn et al., 2012). 


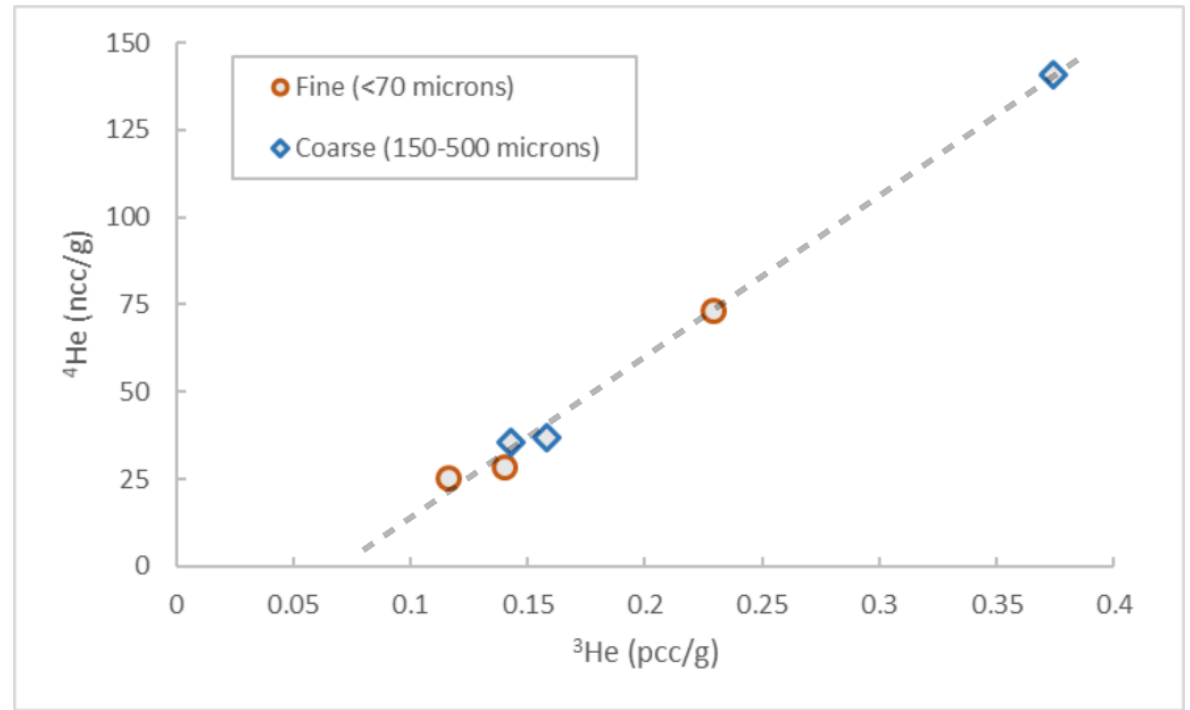

Figure 10: ${ }^{3} \mathrm{He} /{ }^{4} \mathrm{He}$ scatter plot of exposed sample (T2S5, T2S6, and T2S7) results processed at two grain size fractions

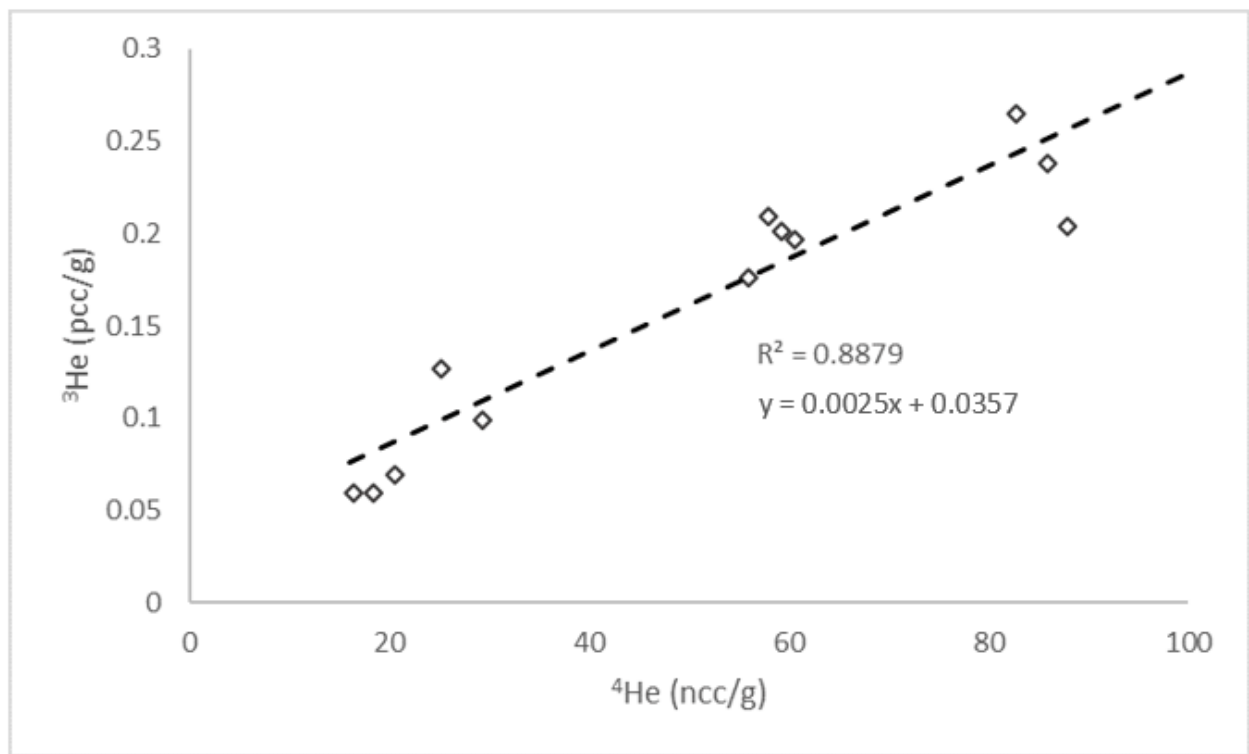

Figure 11: ${ }^{3} \mathrm{He} /{ }^{4} \mathrm{He}$ scatter plot of shielded samples from quarry showing linear trendline and $\mathrm{r}$ squared value. This plot constrains the inherited (mantle) ${ }^{3} \mathrm{He} /{ }^{4} \mathrm{He}$ ratio. 


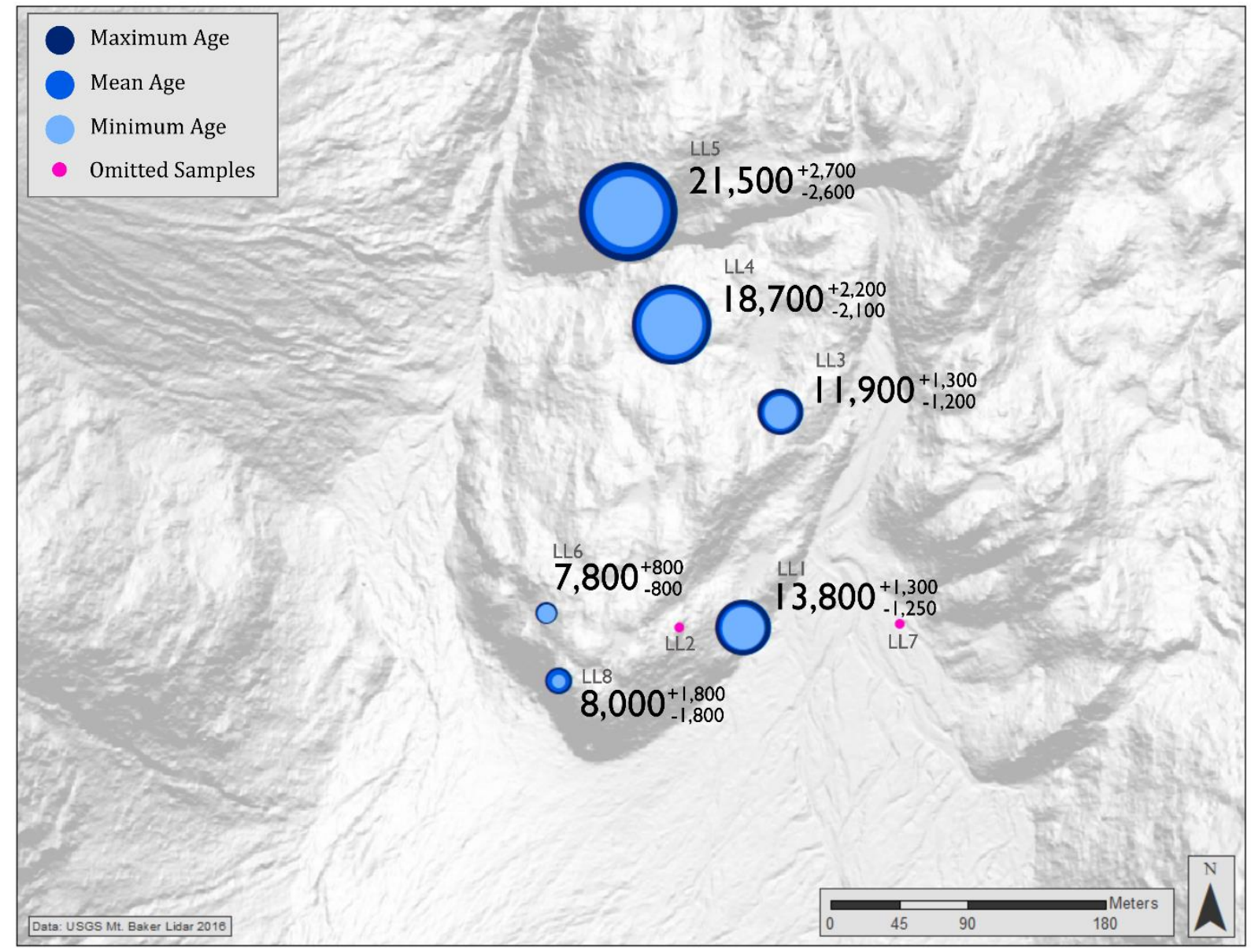

Figure 12: Lowland (pre-Neoglacial) sample sites, indicating model exposure ages. Relative uncertainty (related to ${ }^{3} \mathrm{He} /{ }^{4} \mathrm{He}$ ratio and snow shielding) shown in outer and inner circles at each site. Omitted analyses rejected based on high ${ }^{4} \mathrm{He}$ concentrations. 


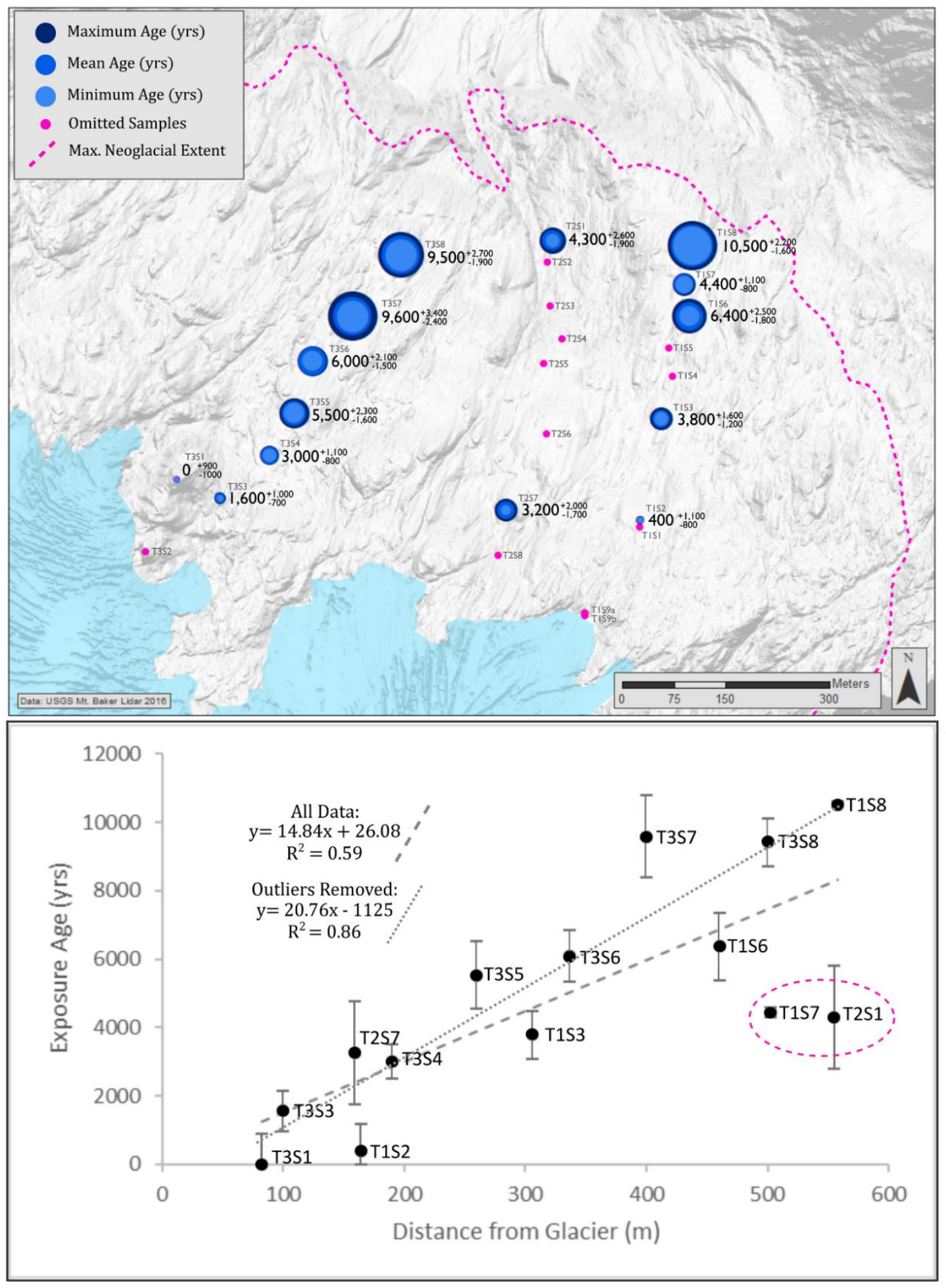

Figure 13: Top: Map view of forefield samples indicating model exposure ages, including uncertainties related to mantle ${ }^{3} \mathrm{He} /{ }^{4} \mathrm{He}$ ratio $(1 \sigma)$ and snow shielding. Bottom: Plot showing sample distance from glacier along glacial flow lines relative to exposure age, including uncertainty related to mantle ${ }^{3} \mathrm{He} /{ }^{4} \mathrm{He}$ ratio $(1 \sigma)$. Outliers circled in plot. 


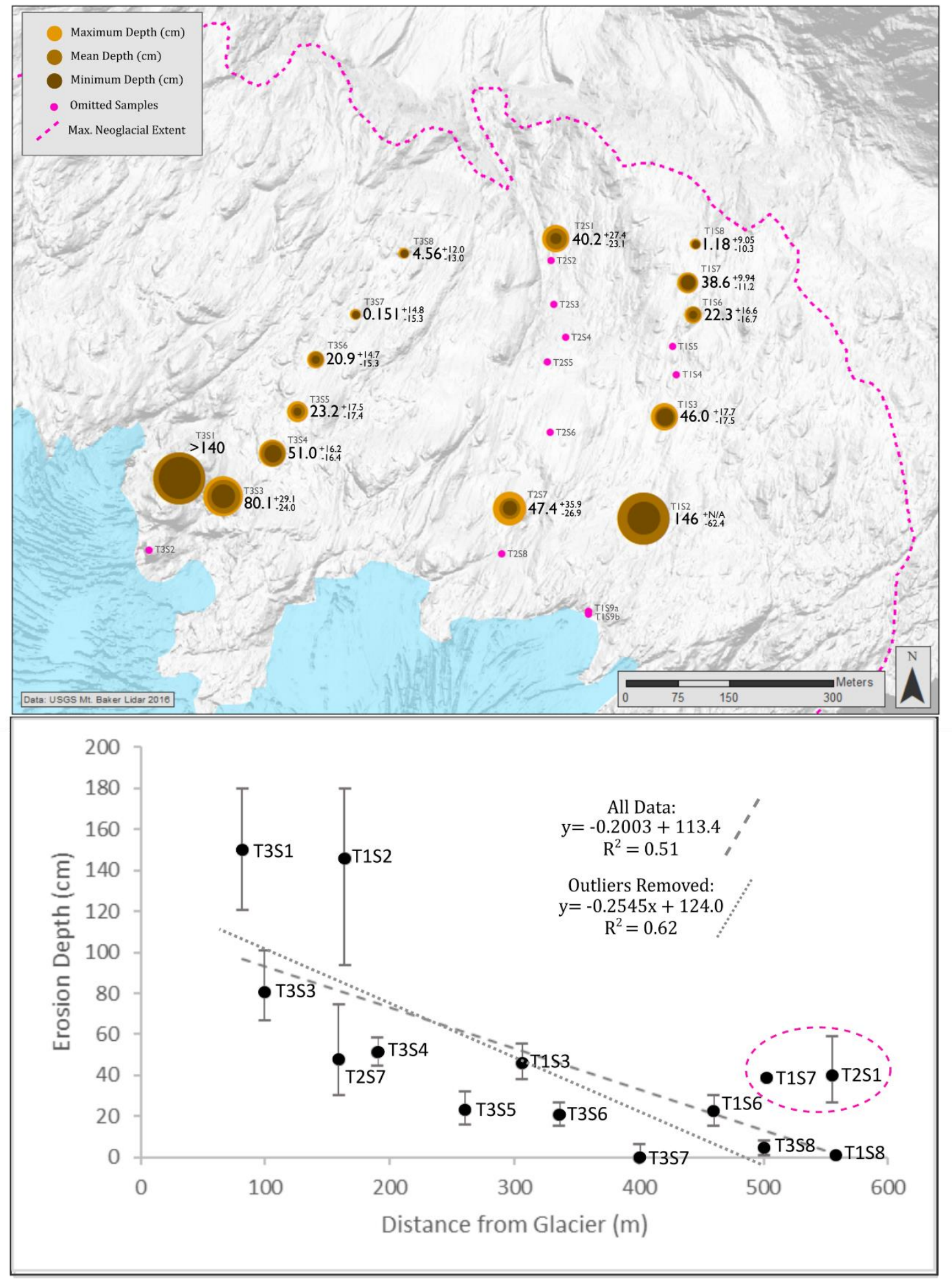

Figure 14: Top: Map view of forefield samples indicating calculated erosion depths, including uncertainties related to mantle ${ }^{3} \mathrm{He} /{ }^{4} \mathrm{He}$ ratio $(1 \sigma)$, period of glaciation, and snow shielding. Bottom: Plot showing sample distance from glacier along glacial flow lines relative to calculated erosion depths, including uncertainty related to mantle ${ }^{3} \mathrm{He} /{ }^{4} \mathrm{He}$ ratio $(1 \sigma)$. Outliers circled in plot. 

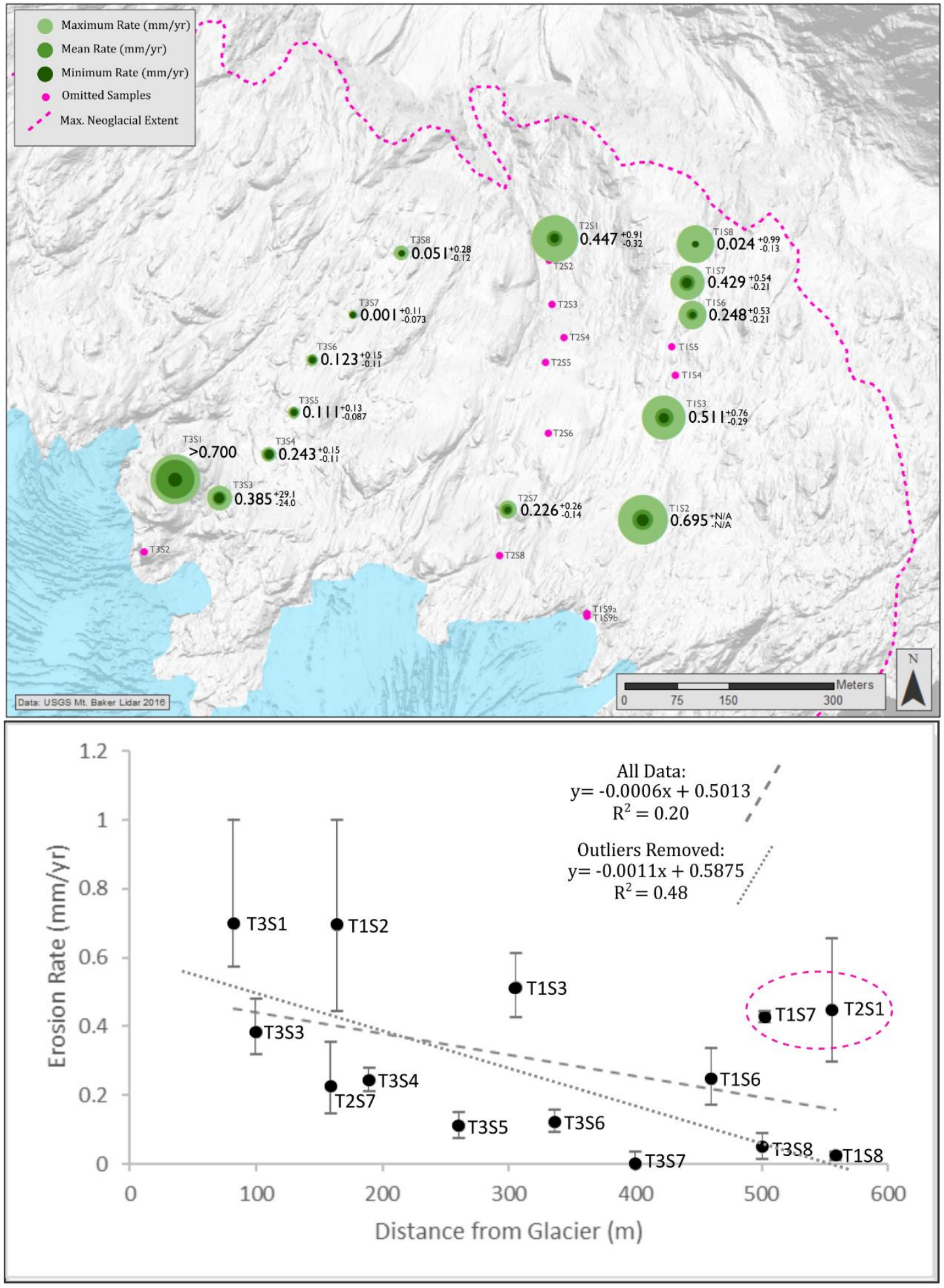

Figure 15: Top: Map view of forefield samples indicating calculated erosion rates, including uncertainties related to mantle ${ }^{3} \mathrm{He} /{ }^{4} \mathrm{He}$ ratio $(1 \sigma)$, period of glaciation, and snow shielding. Bottom: Plot showing sample distance from glacier along glacial flow lines relative to calculated erosion rates, including uncertainty related to mantle ${ }^{3} \mathrm{He} /{ }^{4} \mathrm{He}$ ratio $(1 \sigma)$. Outliers circled in plot. 